\title{
PODER ECONÔMICO E IMPERIALISMO: A Relação entre Público e Privado (A História do Capitalismo)
}

ECONOMIC POWER AND IMPERIALISM: THE RELATION BETWEEN PUBLIC AND PRIVATE:

(The History of Capitalism)

Vicente Bagnoli

\section{Resumo:}

O presente artigo procura analisar brevemente o fenômeno do Poder Econômico e, para tanto, aborda, ainda que de forma sucinta, sua manifestação no decorrer da história, sobretudo da história do capitalismo, para então relacioná-lo com o Poder Estatal e o Poder Privado.

Palavras-chave: Poder Econômico. Poder Estatal. Poder Privado.

\begin{abstract}
:
The present article tries to analyze the phenomenon of the Economical Power and, for this. it approaches. although in a brief way, its manifestation in elapsing of the history, above all of the history of the capitalism, for then to relate it with the State Power and the Private Power.
\end{abstract}

Keywords: Economical Power. State Power. Private Power.

1. Breve análise da manifestação do Poder Econômico no decorrer da História do Capitalismo

Para analisar o fenômeno do Poder Econômico, entende-se pertinente abordar, ainda que de forma breve, sua manifestação no decorrer da história, sobretudo da história do capitalismo, para então relacioná-lo com o Poder Estatal e o Poder Privado.

Ao realizar tal abordagem, deve-se ter em munte "o complexo das relações entre Direito e Poder" que segundo Celso Lafer: "... é um dos grandes temas da reflexão jurídico-política. No mundo moderno essa reflexão tem ligações muito estreitas com o aparecimento do Estado, que transformou o papel do Direito. De fato, o Direito deixou de ser, como era na Idade Média, um quadro de referências da política e passou a ser; com sua crescente positivação pelo Estado - razão explicativa das doutrinas juridicas estatalistas - um instrumento de governo" I

Doutor em Filosofia e Teoria Geral do Direito pela Faculdade de Direito da Universidade de Sào Paulo. Mestre cm Direito Político e Econômıco pela Universidade Presbiteriana Mackenzie, onde é Professor dos Departamentos de Direito Público e Privado; bagnoli@bgadv.com.br 


\section{I.1. Estado agente econômico (séculos XV e XVI)}

Na Idade Média o monopólio da grande atividade comercial era exercido diretamente pelo Estado, ou por particulares que recebiam a concessão do Estado mediante retribuição. Tais agentes privados apresentam, de certa forma. aspectos característicos das grandes concentrações capitalistas contemporâneas.

Na Baixa Idade Média desenvolvem-se no contexto das feiras medievais os elementos do pré-capitalismo comercial, entre eles: as primeiras moedas; os primeiros bancos: as notas promissórias; vales; cheques; letras de câmbio; companhias de navegação, transporte e frete (aluguel); e companhias por ações.

Inicia-se também na Baixa Idade Média o processo de centralização do poder político, que vai dar origem à formação das Monarquias Nacionais. No processo de centralização do poder político o rei se alia a nascente burguesia mercantil e dela extrai recursos para combater a nobreza e formar as Monarquias Nacionais, também denominadas Estados Modernos ou Nações Modernas ou Reinos Modernos.

A formação das Monarquias Nacionais constitui na progressiva centralização política nas mãos dos Reis e isto significou a aglutinação. a conquista e a compra das terras da nobreza feudal, e assim o Rei foi alargando os dominios de seu feudo e acabando por formar e delimitar as fronteiras do seu reino.

Em função do renascimento comercial e urbuno. começa a se desenvolver uma camada social intermediária, a nascente burguesia mercantil (comercial). Neste contesto da Baixa Idade Média, os servos e vilões da Europa Ocidental que apareceram no campo se transformam em camponeses assalariados.

O Rei teve papel fundamental no processo de centralização do poder político, pois é o Rei que representa o Estado, a Nação; delimita seu território. organizando as fronteiras e estabelecendo os limites geográficos de seu reino: organiza um sistema de pesos e medidas; impõem um sistema monetário; e unifica as leis. Tudo isso contribui para facilitar o comércio c para estabelecer um mercado nacional, porque: o Rei apóia e é apoiado pela burguesia; concede à burguesia privilégios e monopólios. principalmente no comércio marítimo e colonial; recebe os impostos que a burguesia paga e com esse dinheiro pode se lançar no processo das grandes navegações e organizar um exército; com o exúrcito organizado o Rei oferece paz, segurança e ordem para a burguesia realizar com tranqüilidade suas transações comerciais; conseqüentemente vai desenvolver o Regime Absolutista e o Sistcma Mercuntilista.

LAFER, Celso. Direito e poder na reflexão de Miguel Reale. In: MIGUEL Realc na UNB. Brasilia: UNB. 1981. p. 59. 
Essa passagem da Idade Média já revela o relacionamento entre Poder do Soberano (Rei, Estado) e da Burguesia (Poder Privado), que constituía na troca de interesses; o Rei governava e contava com o apoio da burguesia para poder governar, a burguesia contava com o apoio do Rei para comercializar.

O Absolutismo Monárquico foi o regime político desenvolvido pelos Reis na Idade Moderna que concentrou todos os poderes em suas mãos. Os Reis não deviam satisfação a ninguém, somente a Deus (teoria do absolutismo do Direitos Humanos divino).

Para a burguesia, a concentração dos poderes nas mãos dos Reis era importante para a formação de um mercado nacional, significando o fim dos particularismos feudais. A unificação das leis, dos pesos e medidas e das mocdas, favoreceu uma maior circulação de mercadorias e conseqüentemente o desenvolvimento do comércio.

Com o Regime Absolutista se tem o Mercantilismo, cuja política econômica desenvolvida pelos Reis na Época Moderna consistiu na constante intervenção governamental na economia e tinha como objetivos básicos o enriquecimento do Estado e o enriquecimento do próprio Rei.

No Mercantilismo surge a distinção entre os monopólios licitos e os ilícitos. Os monopólios lícitos eram aqueles desempenhados diretamente pelo Estado ou por particulares mediante concessão. Basta lembrar do monopólio da metrópole no comércio com suas colônias (pacto colonial). Assim, permitia-se que as metrópoles estocassem metais (ouro, prata) originados desse comércio monopolista, que ia do "produto" comercializado até o transporte das mercadorias (companhias privilegiadas). Para inviabilizar qualquer concorrência com a metrópole era proibida a instalação de manufaturas nas colônias para o processamento de matéria-prima.

A grande vantagem para o Rei com esse sistema consistia em que como soberano, detentor do poder de conceder monopólios e exclusividades, recebia, em contrapartida, impostos e taxas pagas pelo monopúlio, o que assegurava a entrada de recursos nos cofres do Reino. Esta etapa do capitalismo é chamada de capitalismo comercial ou fase de acumulação primitiva de capitais. cujas principais fontes eram a exploração das colônias e o tráfico negreiro.

Nesse período os grandes colonizadores da América, Portugal e Espanha, não se preocupavam em desenvolver suas economias (manufaturas) e. por isso, acabavam utilizando o ouro e a prata que exploravam nas suas colônias americanas para comprar de outros reinos praticamente tudo que necessitavam, em especial da Inglaterra. 
O ouro e a prata que vão para a Inglaterra é o capital necessário para viabilizar financeiramente a Revolução Industrial de 1760.

A Idade Moderna era a época do chamado Antigo Regime. das monarquias nacionais absolutistas de Direitos Humanos divino (política), do mercantilismo e do pacto colonial (economia), e da sociedade estamental determinada pelo nascimento das pessoas (social). O Absolutismo contou com o apoio de filósofos e juristas, chamados teóricos do Absolutismo, que defenderam o regime, dentre os quais se destacam: Maquiavel, Jean Bodin, Thomas Hobbes, Jaques Bossuet e Hugo Grotius. Já o regime de produção protecionista desse período tinha como destaque Colbert e Cromwel.

\subsection{Rupturas econômicas e sociais (séculos XVII e XVIII)}

O lluminismo, também chamado Ilustração ou Era das Luzes, tratava-se de um conjunto de idéias políticas, econômicas, sociais, culturais, religiosas, jurídicas e educacionais, que apareceram nas obras de grandes filósofos do final do século XVIJ e principalmente do século XVIII, com o objetivo de criticar, modificar e acabar com o chamado Antigo Regime. Na Europa essas idéias eram defendidas pela burguesia em luta contra as classes privilegiadas (clero e nobreza) para o fim do Regime Absolutista. Nas Américas eram defendidas pela aristocracia rural contra a burguesia mercantil européia objetivando a Independência.

Os principais nomes do Iluminismo foram Descartes, Isaac Newton e John Locke, precursores do século XVII; Montesquieu, Voltaire e Rousseau, grandes filósofos políticos; Cesare Beccaria, grande jurista; Diderot e D'Alambert, dirigentes da Grande Enciclopédia Francesa; e os economistas fisiocratas franceses Quesnay, Gournay e Turgot, segundo os quais a fonte de riqueza era a agricultura, e os economistas clássicos ou liberais ingleses Adam Smith, Malthus e David Ricardo, que defendiam o trabalho como fonte de riqueza.

Com o Iluminismo, a atuação e intervenção estatal na economia começam a ser modificada. Em 1776, Adam Smith em a Investigação sobre a Natureza e as Causas da Riqueza das Vações, escreve sobre a "mão invisível" expondo que o Estado não deveria intervir no mercado, pois ele se auto-regularia pelas leis da oferta e da procura.

No final da História Moderna ocorrem as chamadas Revoluções Liberais ou Constitucionais ou Burguesas, que pretendem acabar com o chamado Antigo Regime. Os objetivos dessas revoluções eram: politicamente. monarquias constitucionais que caminhassem para parlamentos; economicamente, liberalismo econômico ou política do 
laissez-faire. total liberdade econômica e a conseqüente luta das Colônias pela independência; socialmente, sociedade capitalista com grande mobilidade social, determinando a posição das pessoas pela posse de dinheiro.

No Reino Unido, a Revolução Gloriosa (1688/1689) significou a vitória do Parlamento (legislativo) sobre o absolutismo real (executivo). Com ela a burguesia está com o poder político e o utiliza conforme seus interesses econômicos. A Revolução Gloriosa influencia outras Revoluções Liberais. como a Americana (Guerra de Independência dos Estados Unidos da América - 1776), e a Francesa (1789). Do ponto de vista juridico-filosófico, ela foi justificada por John Locke.

No continente americano ocorreu a Guerra de Independência dos Estados Unidos da América. que teve como causas externas: as idéias liberais defendidas pelos filósofos iluministas; a nova política inglesa de colonização que após 1763 aplica as leis mercantilistas já existentes e estabelece novas leis restritivas em relação as suas 13 colônias.

Importante destacar que nos Estados Unidos da América foi onde frutificaram. em primeiro lugar. as idéias do Iluminismo. e onde foi dado o primeiro golpe no colonialismo Europeu nas Américas, rompendo o pacto colonial. A Independência norte-americana inicia as chamadas Era das Revoluções Atlânticas. Influenciará os movimentos liberais na Europa (Revolução Francesa) e nas Américas (movimentos em prol da Independência).

Enquanto alguns paises, influenciados pelas idéias do Iluminismo, realizavam Revoluções Burguesas, outros países, via de regra economicamente mais atrasados, adotavam principalmente na segunda metade do século XVIII o Despotismo Esclarecido.

Contudo, a maioria das reformas propostas pelos déspotas não apresentou resultados práticos e seus países continuaram, de modo geral, economicamente atrasados. Num pequeno espaço de tempo estouram as Revoluções Liberais em diversos paises da Europa (Revoluções Liberais de 1830 e Revoluções de 1848), bem como o surgimento do socialismo utópico e marxista.

\subsubsection{A Revolução Francesa}

Em 14 de julho de 1789 ocorreu a grande revolução que definitivamente estabelece a quebra de um modelo social até então tolerado, que garantia os privilégios da nobreza. e deixava em segundo plano a classe burguesa, que financiava os descobrimentos e a manutenção dos reis na liderança dos Estados. A Revolução 
Francesu, que se inicia simbolicamente com a queda da Bastilha foi uma revolução feita pela e para a burguesia francesa, que utilizou o povo, classe desprivilegiada, como instrumento revolucionário. A Revolução é finalizada com o 18 Brumário, ou seja, 9 de novembro de 1799, golpe de Estado de Napoleão Bonaparte, dando início ao período napoleônico.

Napoleão significou interna e externamente a consolidação dos ideais burgueses da Revolução. O período napoleônico, compreendido de 1800 a 1815 , significou um avanço nas idéias liberais. Além de chocar-se com os interesses da burguesia comercial e industrial inglesa, que sentem sua hegemonia ameaçada, Napoleão também se choca com os países absolutistas que temem a expansão das idéias liberais.

\subsubsection{A Revolução Industrial}

A Primeira Fase ou a Primeira Revolução Industrial vai de 1760 à aproximadamente 1860 , estando restrita basicamente à Inglaterra. O primeiro setor mecanizado foi o têxtil, e ocorre a substituição da ferramenta pela máquina e como conseqüência o desenvolvimento do sistema fabril. Importância deve ser atribuída ao binômio carvão e ferro, e o desenvolvimento da metalurgia e da siderurgia. Utiliza-se o vapor como fonte de energia.

A Segunda Fase ou Segunda Revolução Industrial inicia-se a partir de 1860, atingindo no continente europeu Bélgica, França, norte da Itália, Alemanha e Rússia. Fora da Europa a Segunda Revolução Industrial atinge dois países: os Estados Unidos da América (EUA), após 1865 com o término da Guerra de Secessão, e o Japão após 1868, o grande Imperialista do Oriente. A energia elétrica e o petróleo despontam como novas fontes de energia. Aparece o aço (processo Bessemer) e o motor de explosão. Ocorrem grandes revoluções nos meios de comunicação, nos meios de transporte, na agricultura e na pecuária.

$\mathrm{Na}$ Segunda Revolução Industrial a partir do capitalismo industrial desenvolve-se o capitalismo financeiro, ou seja, a aliança do capital industrial com o bancário, visto que os industriais necessitam de capital para contratar operários, construir grandes fábricas, possuir estoques de matérias-primas, máquinas e uma adequada administração. Desenvolve-se também uma nova política econômica, a política do laissez-faire ou liberalismo econômico. que não aceita mais a intervenção do Estado na vida econômica. Contudo, o resultado dessa liberalização foi o surgimento de grandes sociedades anônimas, grandes conglomerados de empresas (holdings) e acordos internacionais para dividir mercados e limitar a concorrência (cartéis), superando a fase 
do capitalismo liberal e concorrencial. O chamado imperialismo ou neocolonialismo é acirrado, principalmente na segunda metade do século XIX. Surge o proletariado e novas doutrinas sociais, como o socialismo, o anarquismo e o sindicalismo.

Por fim, tem-se a Terceira Fase ou Terceira Revolução Industrial, com início no século XX, principalmente após a $2^{\mathrm{a}}$ Guerra Mundial, até os dias atuais. ${ }^{2} \mathrm{~A}$ industrialização atinge diversos países e novas fontes de energia são utilizadas como a nuclear (atômica), e com a crise do petróleo busca-se fontes alternativas, como a energia solar e o álcool. Ocorre a automatização da produção, produção em série e em massa; a melhoria nos meios de comunicação e nos meios de transporte.

Nesta Terceira Fase ganha força o capitalismo monopolista, das grandes multinacionais, iniciado ainda na $2^{\mathrm{a}}$ Revolução Industrial. Ocorre também o crescimento do proletariado, dos movimentos sindicais e aparecimento de partidos de trabalhadores.

$\mathrm{Na}$ economia a Revolução Industrial significou: (i) a revolução nos meios de comunicação, transportes, agricultura e pecuária; (ii) o desenvolvimento de uma nova política econômica (liberalismo econômico); (iii) a procura de colônias fornecedoras de matéria-prima e consumidoras de manufaturados (neocolonialismo); (iv) a procura de zonas de influência econômica e pontos estratégicos; (v) a divisão do mundo em países adiantados ou produtores industriais e países atrasados ou produtores de matéria-prima; (vi) o investimento de capitais da Europa industrializada em outros paises; (vii) o interesse inglês no fim do tráfico negreiro e na independência da América Latina; e (viii) o desenvolvimento intenso do sistema fabril. Socialmente implicou: (i) na separação do

Interessante a análise histórica da humanidade feita por Alvin Toffler: "Até agora a raça humana suportou duas grandes ondas de mudança, cada uma obliterando extensamente culturas ou civilizaçōes e substituindo-as por modos de vida inconcebiveis para os que vieram antes. A Primeira Onda de mudança a revolução agrícola - levou milharıs de anos para acabar. A Segunda Onda - o acesso da civilização industrial - durou apenas uns poucos 300 anos. Hoje a História é ainda mais acelerativa e é provável que a Terceira Onda atravesse a História e se complete em poucas décadas. (...) a civilização da Terceira Onda começará a cicatrizar a ruptura histórica entre o produtor e o consumidor, gerando a economia do prossumidor de amanhã. Por esta razão, entre muitas, poderia - com alguma ajuda inteligente nossa résultar na primeira civilização verdadeiramente humana da História registrada. (...) a Primeira Onda começou por volta de 8000 a.C. e que dominou a terra sem qualquer desafio até 1650 e 1750 d.C. A partir deste momento, a Primeira Onda perdeu ímpeto, enquanto a Segunda Onda ganhava força. A civilização industrial, produto desta Segunda Onda, dominou então o planeta por sua vez, até atingir a altura máxima. Este último ponto máximo histórico ocorreu nos Estados Unidos, durante a década iniciada por volta de 1955 a década que viu os trabalhadores de colarinho branco e de serviços gerais excederem em número os trabalhadores de macacão. Esta foi a mesma década que viu a introdução generalizada do computador, o jato comercial, a pilula anticoncepcional e muitas outras inovações de alto impacto. Foi precisamente durante esta década que a Terceira Onda começou a ganhar força nos Estados Unidos. Desde entào chegou - em datas um pouco diferentes - à maioria das outras naçōes industrializadas, inclusive a Grã-Bretanha. a França, a Suécia, a Alemanha, a União Soviètica e o Japão. Hoje todas as nações de alta tecnologia oscilam sob a colisão entre a Terceira Onda e as obsoletas economias e instituições da Segunda. Compreender isto é o segredo de dar sentido a grande parte do conflito político é sucial que vemus em redor de nos". (TOFFLFR, Alvin. A Terceira Onda. 6. ed. São Paulo: Record, 1986. p. 24, 25 e 28). 
capital e dos meios de produção e do trabalho; (ii) no aumento da população européia que irá determinar uma corrente migratória principalmente para as Américas e também África e Índia; (iii) no êxodo rural; (iv) no surgimento das associações operárias (trade unions, espécie de sindicatos) em razão do crescimento do proletariado e a pressão decorrente na burguesia; e (v) no desenvolvimento de novas doutrinas sociais como o socialismo e o anarquismo.

No campo econômico a Revolução Industrial promoveu a grande modificação na estrutura do mercado, realizando a grande revolução no setor econômico, enquanto a Revolução Francesa, ${ }^{3} 1789$, garantiu a ruptura com o modelo sócio-jurídico até então existente.

\subsection{Liberalismo Econômico (século XIX)}

Foi em pequena parte do século XIX em que as idéias liberais foram postas em prática nos Estados, com a ausência do Poder Estatal na Economia. O Estado não mais intervém no domínio econômico. limitando-se à questões da esfera cível.

Neste sentido, aquele que sente seu direito ameaçado, que lute por ele. Tal situação caracteriza o espaço temporal da história do capitalismo em que o Estado estava ausente da economia. Os resultados vão desde o descontentamento da população norteamericana com a constituição de trustes que limitavam a livre concorrência. e até mesmo a crise da Bolsa de Nova York em 1929.

O que ocorreu nos Estados Unidos da América na segunda metade do século XIX foi a diminuição do número de empresas concorrentes e a reunião do poder econômico em poucos agentes econômicos; era um típico momento de concentração.

Não demorou muito e a população, dentre os quais consumidores, agricultores, trabalhadores e pequenos empresários, bem como a imprensa, principalmente a partir de 1880, contesta a concentração do poder econômico, os preços de monopólio, a sujeição de diversos agentes do mercado ao poder econômico e as práticas comerciais consideradas imorais para eliminar a concorrência. Assim, a

Segundo Celso Delmanto, “... anteriormente à Revolução Francesa não se podia cogitar de infração concorrencial, pois inexistia, até então, a verdadeira compctição. (...) antes do movimento francês as prolissões estavam rigidamente controladas pelas corporações e vigoravam monopólios nas poucas indústrias que, mercê de decretos. excrciam a fabricação com prática exclusividade. $O$ trabalho dos artesãos achava-se regulado por aquelas suas próprias associaçōes, que impediam qualquer possibilidade de competição, com a estipulação de preços, modelos e serviços. Além de tudo, o campo da possivel disputa estava limitado às próprias cidades e regiões dos artifices. Foi aquela Revolução politica que deu. em 1791, o sinal de partida para a corrida da competição, e, poucas voltas depois. já a revolução industrial agitava a sua bandeira, aumentando a velocidade da carreira: iniciava-se a liberdade de disputar" (DELMANTO, Celso. ('rimes de concorrència desleal. São Paulo: José Bushatsky Editor. 1975. p. 5 c 6.). 
liberdade de atuação no mercado pregada pelo Liberalismo começa a ser contestada nos EUA no final do século XIX.

Enquanto a contestação ao modelo concentracionista ganhava força, empresários e economistas defendiam que a concorrência consistia em fator regulador do mercado, garantidora do incremento da produção e da expansão da indústria. A evolução natural conduziria a substituição da concorência entre as empresas pela colaboração, quando só os agentes mais fortes resistiriam. Assim, interpretando Adam Smith e Charles Darwin no modelo liberal, aplicar-se-ia no campo da Economia e do Direito a seleção natural aos derrotados pelos mais fortes na concorrência.

A bandeira do antitruste, também face ao seu grande apelo popular da época. faz com que os candidatos à Presidência dos Estados Unidos da América nas eleições de 1888 defendessem a criação de uma lei que fosse capaz de controlar o poder econômico. O senador John Sherman apresentou nesse mesmo ano um projeto de lei acerca dessa matéria que foi discutido pelo Congresso norte-americano. É então promulgado em 1890 o Sherman $A c t,{ }^{4}$ considerado o marco legal do antitruste.

Certo é que num curto período constatou-se que não se podia deixar a economia e o Direito separados, cada qual desempenhando seu papel. As ciências tinham que conversar, pois o direito do dever ser, jamais acompanharia a realidade econômica do ser, e com isso o próprio Capitalismo estaria comprometido.'

4

O Sherman Act foi promulgado numa época (final do século XIX) em que os direitos sociais despontavam no mundo como algo necessariamente a ser protegido pelo Estado. Sua preocupação com a proteção dos consumidores contra os malefícios de monopólios e cartéis e, portanto, o aparecimento de um Direito da Concorrência, tem origem relacionada às questões de trabalho. Conforme ensina Evaristo de Moraes Filho, "o Direito do Trabalho í um produto típico do século XIX. Somente nesse século surgíram as condições sociais que tornaram possivel o aparecimento do Direito do Trabalho como um ramo novo da comum ciência juridica, cum características próprias e autonomia doutrinária" (apud MARANHÃO, Délio: CARVALHO, Luiz Inácio B.Carvalho. Direilo do Trabalho. 17. ed. Rio de Janeiro: Fundação Gerúlio Vargas, 1996. p. 14 e 15).

Neste sentido, escreve Max Weber acerca da ordem juridica e da ordem econômica: “... É cvidente que os dois modos de consideração se propõem problemas totalmente heterogêneos, que seus "objetos " não podem entrar imediatamente em contato, e que a 'ordem juridica` ideal da teoria do Direitos Humanos não tem diretamente nada a ver cum o cosmos das ações econômica efetivas, uma vez que ambos se encontram em planos diferentes: a primeira, no plano ideal de vigência pretendida: o segundo, nos acontecimentos reais. Quando, apesar disso, a ordem econômica e a juridica estão numa relaçāo bastante intima, è porquc esta última ċ entendida não $\mathrm{cm}$ seu sentido juridico mas no sociológico: tomu vigência empírica. O sentido da palavra 'ordem juridica' muda então completamente. Não significa um cosmos de normas interpretáveis como logicamente 'corretas', mas um complexo de motivos efetivos que determinam as ações humanas reais. Cabe interpretar isso em seus detalhes" (WEBER, Max. Economia e sociedade. Tradução Regis Barbosa e Karen Elsabe Barbosa. 4. ed. Brasilia- Editora Universidade de Brasília, 2000. v. 1. p. 210 e 211 ). 


\subsection{Direito Econômico (século XX)}

Com a criação de novas indústrias e o crescimento dos intercâmbios internacionais a economia do continente europeu vivia constantes progressos, mas aos poucos as grandes potências européias começam disputar os territórios disponíveis. Tal fato guarda total relação com o imperialismo dos anos de 1871 a 1914 e as relações internacionais dessa época. ${ }^{6}$

Enquanto a Inglaterra destacava-se por ser a maior detentora de capitais, a França dispunha de importantes formas de pressão, decorrência de seu poder econômico sobre diversos Estados. Diferentemente da Rússia, da Itália e do Império AustroHúngaro, que não tinham condições de combater a hegemonia franco-britânica, a Alemanha com o desenvolvimento de sua indústria exportadora despontou como nação a oferecer uma concorrência equilibrada às demais potências. ${ }^{7}$ Mas os europeus também tinham dois novos concorrentes, um vindo da América e outro do Oriente. Os Estados Unidos da América e o Japão. em razão dos seus consideráveis progressos econômicos e das fortes marinhas de guerra, passavam a ter importante participação dentro de alianças e conferências.

O crescimento armamentista no início de 1914 sinalizava que a paz era precária. Em julho desse mesmo ano estoura a crise no dia 28 de junho com o assassinato. em Sarajevo, do arquiduque herdeiro do Império Austro-Húngaro, Francisco Ferdinando. Com esse fato o Imperador da Áustria tentou eliminar a influência sérvia nos Bálcãs, atitude endossada pela Alemanha, que em 03 de agosto declara guerra à França. A Inglaterra. temerosa de que França e Rússia não conteriam a ameaça de uma

- Escreve Hannah Arendt que: "As depressōes dos anos 60 e 80 . que deram inicio à era do imperialismo, forçaram a burguesia compreender pela primeira vez que o pecado original do roubo, que séculos antes tomara possivel o 'original acúmulo de capital' (Marx) e gerara todas as acumulaçōes posteriores, teria eventualmente de ser repetido, a fim de evitar que o motor da acumulação parasse de súbito. Diante de tal perigo, que ameaçava a nação inteira com um colapso catastrófico da produção, os produtores capitalistas compreenderam que as formas e leis do seu sistema de produção "haviam desde o inicio sido previstas para loda a lerra".. (ARENDT, Hannah. Origens do tolalitarismo: Anti-semitismo, Imperialismo, Totalitarismo. São Paulo: Companhia das Letras, 2004. p. 178).

A nova mentalidade politica da época ditava o desejo dos Estados conseguirem prestigio e poder. Os grandes choques imperialistas eram inevitáveis, já que cada nação colonizadora visava à consolidação de seus dominios. Importante também destacar que as relaçôes internacionais de 1871 a 1890 foram marcadas pela sagacidade de Bismark, que além de transformar a Alemanha em uma grande potência, buscou uma nova ordem européia com a confirmação do poder alemão. Já as relações internacionais de 1890 a 1914 ficam marcadas pelo firm das desavenças entre Inglaterra e França e, com isso, a constituição de uma ação comum denominada Entente Cordiale. Nessc interim. cstoura em 1905 a primeira crise marroquina e a aliança franco-russa se aproxima da Entente Cordiale, surgindo a Triplice Entente. Ocorte também de 1908 a 1909 a tensão balcânica e a crise na Bósnia e em 1911 a segunda crise marroquina. De 1912 a 1913 o continente europeu observa as guerras dos Bálcãs. 
possivel hegemonia alemã, e assim perigosa aos interesses britânicos e ao equilíbrio europeu, interfere no conflito em 4 de agosto.

Inicia-se a $1^{\text {a }}$ Grande Guerra Mundial (1914-1918) com França, Rússia, Inglaterra, Sérvia e Bélgica (Entente) contra a Alemanha e o Império Austro-Húngaro. Com o decorrer dos tempos outros países vão se envolvendo no conflito.

Evidentemente os armamentos para os beligerantes tinham grande importância, o que levou as nações mobilizarem suas indústrias, representando uma verdadeira intervenção do Estado na economia. ${ }^{\gamma}$

Os bancos credores dos países da Entente exercem grande pressão na política do presidente norte-americano Wilson, que, com a destruição de navios de guerra de bandeira estadunidense, intervém no conflito em 02 de abril de 1917. defendendo a liberdade e a democracia.

Em meio à guerra despontam correntes pacifistas, na Suíça, por exemplo. onde socialistas, como Lênin, defendiam a subordinação de tudo à causa da revolução proletária, já que a luta pela paz seria apenas a luta pela realização do socialismo. Somavam-se a essas correntes pacifistas ideais de sindicalistas na Alemanha, na França e. principalmente, na Rússia. Com o tempo vão desencadear greves.

A desagregação das potências ligadas à Alemanha, em razão de movimentos revolucionários internos, e a ameaça da ofensiva aliada, contribuem para o enfraquecimento desses países. Em 09 de novembro de 1918, com a abdicação de Guilherme I. é proclamada. em Berlim. a República Alemã. O novo governo, logo em II de novembro do mesmo ano, assina em Rethondes um armistício. pondo fim a Primeira Guerra Mundial. Em 28 de junho de 1919 é assinada a Paz de Versalhes.

$\mathrm{Na}$ Itália. as incertezas e o descontentamento das classes mais pobres com o pós-guerra representavam uma crescente que desagradava a burguesia e os grandes proprietários. Com isso. esses dois segmentos da sociedade passam a apoiar os fascistas. um grupo de políticos liderado por Mussolini e decidido a conter o avanço revolucionário pela força. Outros países da Europa, diante das dificuldades do pósguerra, também sucumbem a regimes ditatoriais, como Portugal, Espanha, Hungria, lugoslávia. Turquia, Polônia, Bulgária e Grécia.

Conforme escreveu Paula A. Forgioni, "Já no primeiro quartel do século XX têm lugar alguns acontecimentos que modificam a postura do Estado em face da regulamentação e condução da economia. Em 1914, inicia-se a Primeira Grande Guerra. Os Estados vão divisando que, como disse Comparato, as guerras não se ganham apenas nos campos de batalha. Verifica-se, pois, uma atuação no sentido de organizar a economia, direcionando-a para a guerra. Um surto de regulamentação estatal da atividade econômica se faz. presente, não obstante tenha sido julgado por muitos como temporário e eventual" (FORGIONI. Paula A. Os fundamentos do Antirmuste. São Paulo: Revista dos Tribunais, 1998. p. 77.) 
A França, apesar de vitoriosa, teve parte de seu território devastado, compreendendo as regiões mais ricas e industrializadas. Os salários dos trabalhadores foram reduzidos e o custo de vida aumentou, agravando a condição de vida do operariado e da classe média. Diante desse quadro, o Conselho Geral dos Trabalhadores (CGT) fez reivindicações como uma jornada mínima de oito horas e igualdade salarial entre homens e mulheres. Em 1926, o presidente Poincaré conseguiu estabilizar a moeda e a indústria se recuperou, inclusive com uma balança comercial favorável, fazendo da França uma exceção na Europa, até a crise de 1929.

A Inglaterra teve grandes dificuldades para se adaptar às necessidades econômicas do pós-guerra. Além da substituição do carvão pela eletricidade e pelo petróleo, a concorrência com a produção industrial de países como Brasil, Argentina e México, implicaram na redução das exportações inglesas. O crescente conflito social e a ineficácia dos poderes públicos aumentavam as dúvidas entre o liberalismo e o intervencionismo.

$\mathrm{Na}$ Alemanha a insatisfação da população era generalizada. Eleita uma Assembléia Constituinte, reunida em Weimar, foi elaborada uma Constituição em agosto de 1919, estabelecendo a Alemanha como uma República Parlamentar. Contudo, o exército e a alta burguesia se mostraram mais fortes que a República de Weimar."

O sentimento antisemita também começa a surgir, atribuindo a judeus e marxistas o insucesso alemão na Guerra. O nacionalismo vai conquistando espaço na sociedade e o Partido Nacional-Socialista Trabalhador Alemão (NAZI), liderado por Adolf Hitler, começa a despontar com um programa que denunciava judeus. marxistas e estrangeiros e prometia trabalho a toda população.

Os Estados Unidos da América foram os grandes beneficiados da Guerra. pois enriqueceram com as exportações de matérias-primas e produtos industrializados para atender os mercados da Europa e também da Ásia e da América do Sul. ${ }^{10}$

9 Conforme escreve Gilberto Bercovici: "A experiência histórica da República de Weimar (1918-1933) i marcada por um sistema politico que perde sua legitimidade e capacidade de luncionamento à medida em que é confrontado com crises profundas no tocante à modernização econômica, social e cultural. A situação sócio-econômica de estagnação do periodo de Weimar, marcada por estas inúmeras crises, impossibilitou a existência de uma conjuntura que permilisse a realização dos compromissus constitucionais sociais com o crescimento cconômico. O questionamento da legitimidade politica da Constituição foi agravado, portanto, com a crise econômica" (BERCOVICI, Gilberto. Constituição "' estado de exceção permanente: atualidade de Wiimar. Rio de Janciro: Azougue Editoral, 2004. p. 21.)

Após um grande crescimento econômico norte-americano, a Europa não conseguia absorver os elevados estoques americanos de produtos e mercadorias. o que resultou na profunda depressão de $1920 \mathrm{e} 1921$. Em meio a esse cenário econômico, o republicano Warren Harding é eleito presidente dos EUA e. ligado ao grande empresariado (big business), abstém-se de qualquer intervenção no domínio econômico e, receoso da concorrência das indústrias européias c japonesas e do Canadá na área agricola, eleva as tarifas protecionistas. Nos anos seguintes, de 1923 a 1929, o crescimento da produção industrial norte-americana atingiu $64 \%$. com destaque também a indústria de bens-de-consumo e a implantação do the american way 
Em meio à prosperidade, que erroneamente os americanos acreditavam permanente, não-obstante pontos fracos da economia como o desemprego agravado pela mecanização das indústrias e a crise agrícola, resultado dos baixos preços das mercadorias e a conseqüente impossibilidade dos agricultores adimplirem seus empréstimos, desponta a crise causada também pela superprodução e pelas especulações. Entre 1925 e 1929 as cotações em Wall Street cresceram duas vezes mais à produção industrial que, por sua vez, não registrava aumentos no consumo.

No inicio de outubro de 1929, banqueiros e investidores de Wall Street, temerosos com o resultado apresentado por diversos índices e as estatísticas que revelavam uma baixa no preço do ferro, aço e cobre, mas, sobretudo, em produtos industriais como o automóvel, indicativo da prosperidade norte-americana, ordenaram a venda maciça de ações. Contudo, o agravamento do pânico ocorreu em 24 de outubro, com o "crack da bolsa de Nova York" Nessa data, conhecida como a Quinta-feira Negra, 16 milhões de títulos foram lançados no mercado sem encontrar compradores.

Os bancos americanos em uma tentativa para superar as suas dificuldades cessam a oferta de créditos aos outros países e repatriam capitais investidos à curto prazo. A mobilidade de capitais que outrora possibilitou a prosperidade de países, agora revelava a face ruim e perigosa da interdependência econômica. Exceção à URSS, onde já não mais existiam os fundamentos econômicos do capitalismo internacional, o mundo inteiro sofre os efeitos da crise de 29.

Diversos incidentes sociais, agravados pelo desemprego generalizado, assolaram principalmente grandes potências, reaparecendo o anti-semitismo e as idéias do nazismo. Numerosos comerciantes e pequenos industriais faliram diante da impossibilidade de concorrer com grandes empresas, muitas das quais protegidas do Estado. A crise também demonstrava a incapacidade dos governos liberais em lidar com a situação, que exigia a intervenção Estatal. Aos poucos o Estado começa a atuar na

of life, cujo simbolo era o automóvel. A indústria adotava como regra a produção em massa, pois a padronização dos produtos além de facilitar a fabricação em série, a produtividade aumentava com o emprego sistemático da mecanização. A concentração de empresas ganhou destaque, e os Irusts e as holdings dominaram a economia. Exemplos que podem ser citados é o caso da United States Stecl Corporation, dependente do grupo Morgan e controladora de $60 \%$ da produção de aço, a General Motors e a Ford, detentoras de dois terços da indústria automobilística, e no mercado de refinação e distribuição de petróleo a quase hegemonia da Standard Oil e a Socony e Vaccum, do Grupo Rockfeller, e a Gulf Oil, do Grupo Mellon. As estruturas da economia capitalista aparentemente eram sólidas. Os governos apenas atuavam com relação a problemas monetários e aduanciros, recusando-se a qualquer intervenção econômica. Com o crescimento da capacidade e da produção mundial a concorrência fícou bastante acirrada e os paises industrializados, travando diversas guerras econômicas. constituem blocos internacionais que além de fixar quotas de produção, também repartiam mercados e delimitavam zonas de exploração. Nesse sentido, produtores franceses, alemães, belgas e luxemburgueses fundam em 1926 o Cartel do Aço, ¿ em 1928 a Standard Oil of New Jersey, a Royal Dutch Shell e a Anglo-Iranian criamo Cartcl Internacional do Petróleo. 
economia. O desemprego foi combatido com grandes obras públicas. Em troca da ajuda financeira a algumas empresas o Estado passava a ter certo poder e controle sobre elas. O Estado. mais do que um simples árbitro e organizador da economia, revelou-se forte interventor, regulamentando produção, fixando taxas de produção e salários e conciliando interesses contraditórios. ${ }^{11}$

Com uma política intervencionista do Estado na vida econômica, Roosevelt inaugurou em 1933 uma nova fase da história sócio-econômica, e porque não também jurídica, num programa de reformas denominado New Deal (nova distribuição). Com medidas fortes e pontuais, como a suspensão temporária de créditos bancários, o ajuste de preços e salários e a realização de grandes obras públicas para absorver mãode-obra ociosa, o New Deal se mostrava a resposta do capitalismo às exigências impostas pela crise de $1929 .{ }^{12}$

Na Alemanha os efeitos da crise de 1929 também eclodiram. Prova disso, as eleições de 1932. Os nazis, nessa ocasião, conquistaram 230 assentos no Reichstag (Parlamento), o que correspondia a $37,3 \%$ dos votos. Tal fato foi possível graças ao apoio dado pela burguesia que, empobrecida, deixa os partidos moderados e deposita suas confianças no nacional-socialismo. Por influência do ex-chanceler Von Papen,

"Assinala Paula A. Forgioni: "Assim, muito embora sempre se tenha verificado a atuação do Estado na economia, a partir do início do século XX, a quantidade de normas emanadas aumentou sensivelmente, de forma a fazer ver uma interferência não apenas episódica, mas organizada c sistemática. O Estado passa a dirigir o sistema, com o escopo de evitar as crises" (F()RGIONI, Paula A. Os fundamemtos do Antitruste. São Paulo: Revista dos Tribunais, 1998. p. 78.)

12 A estabilidade econômica foi então sendo alcançada com medidas que objetivavam o aumento geral do consumo, o controle da produção e a regulamentação da concorrência. O Agricultural Adjustment Act (1933) pretendia com o fornecimento de crédito aos agricultores resolver a siluação de catástrofe da agricultura norte-americana. o National Industrial Recovery ACt (1933) objetivava a redução significativa da taxa de desemprego e viabilizar ganhos às empresas e salários aos trabalhadores. tanto que sc estabeleceu entrc patrões e empregados da indústria e do comércio o Código de Concorrència Local. assegurando aos trabalhadores um salário minimo e liberdade sindical. Tal medida contribui fortemente para o desenvolvimento sindical e em 1935 a Lei Wagner ratificou a liberdade sindical e o direitu de greve. O New Deal, apesar do ritmo lento da retomada econômica e da morosa redução do desemprego, foi uma fase de destaque na história contempurànea nurte-americana, tanto que Roosevelt foi reeleito e governou por mais de doze anos. A ingerência do Estado nas áreas de atuação até então da iniciativa privada, e a interferência do governo federal no campo da livre concorrência, significou a transferência do centro motor da economia de Wall Street para Washington. "No desempenho dessa sua nova função de direção da economia. o Estado utiliza instrumentos juridicos que lhe permitem estabilizar, estimular e dirigir o rumo de sua economia sem apelar para a ditadura e substituir um sistema baseado na propriedade por um sistema de poder ostensivo Essús instrumentos viabilizarão. mediante a dirç̧ão do comportamento dos agentes econômicos, não apenas a preservação, mas a condução do mercado. Dai falarmos em técnicas de direção sobre o mercado, de que se utiliza o Estado em sua função de implementação de uma política pública" FORGIONI, Paula A. Us fundamentos do Antitruste. São Paulo: Revista dos Tribunais, 1998. p. 79. 
bastante ligado aos industriais alemães, o presidente Hindenburg nomeia em 1933 Adolf Hitler, que havia acatado os interesses da alta burguesia, para chanceler alemão. ${ }^{13}$

No Oriente, o Japão obteve resultados positivos com a $1^{\text {a }}$ Guerra Mundial, uma vez que o fim da concorrência com a indústria européia, e até mesmo norteamericana, possibilitou suas exportações para a Ásia, Austrália e América Latina, bem como o desenvolvimento de sua produção química e metalúrgica."

Na China a Guerra de 1914 possibilitou o desenvolvimento da indústria, com importantes repercussões para a sociedade. A burguesia, na verdade, foi a grande beneficiária e durante a Guerra dominou a indústria leve, notadamente a têxtil. Para assegurar a ordem social, a burguesia defendia a unificação política e a independência nacional, que poderia libertar a indústria chinesa da concorrência estrangeira.

As relações internacionais em 1932 iniciam uma fase de grande instabilidade, agravada pela crise econômica e a política imposta pelas ditaduras. As crises internacionais se agravam até 1939 e precipitam a Segunda Guerra Mundial. ${ }^{15}$

13 O governo nacional-socialista implantado pelo Führer introduziu um dirigismo Estatal para controlar o trabalho e a produção, mas sem abalar as estruturas capitalistas do país. Integrou os organismos agricolas, industriais c comerciais para adequar a produçăo e viabilizar as diretrizes governamentais. O Estado também fixava a jornada de trabalho, salários e as margens beneficiárias das empresas, e suprimiu o direito de greve e a liberdade sindical. Os planos quadrienais se iniciam em $1933 \mathrm{com}$ os objetivos primordiais de reduzir o desemprego e ruvitalizar a indústria e o ruarmamento. O segundo plano quadrienal começa em 1937 com o intuito de tornar a Alemanha independente das importações de matérias estratégicas, nacionalizando a produção de produtos sintéticos como carburantes, petrólco e borracha. O resultado foi surpreendente e em 1939 a indústria alemã já era a segunda maior do mundo. A organização do Estado Alemão foi estabelecida por Hitler como a nova ordem para marcar mil anos de história. Essa política foi implementada num Estado totalitário, nacionalista e racista. "Como é sabido por todos. a economia alemã, princıpalmente desde o final do século XIX, é bastante cartelizada. O governo, por sua vez, não somente permilia os cartéis como incentivava sua criação e desenvolvimento. Sob o regime nazista, o fenômeno acentua-se ainda mais", JANICKI, Thomas; RUPPELT, Hans Jürgen. Germânia Federale. In: BIANCHI, Patrizio; GUALTIERI, Giuseppina (Orgs.). Concorrenza e controllo delle concentrazioni in Europa. Bologna: Il Mulino, 1993. p. 247-277, apud FORGIONI, Paula A. Os fundamentos do Antitruste. São Paulo: Revista dos Tribunais, 1998. p. 83.

14 ('ontudo, após um periodo de prosperidade econômica o Japão sofrúu as conseqüências da depressão e em 1921 o desemprego inspirou a propagação do comunismo pelo pais. Nessa époća, a economia c a politica do pais era manipulada pelos aristucratas (zuibalsus). Os trustes eram bastante comuns, como o Mitsubishi, que reunia bancos e companhias marítimas, e financiava o liberal Partido Minseito. defensor da expansão pacilica, e o Mitsui, controlador da indústria pesada, e ligado ao conservador Partido Seiyuai. defensor da expansão armada. Os militares, que não simpatizavam nem com os liberais, nem com us conservadores, comandados pelo general Araki e apoiado pelos nacionalistas passam a dominar o cenário político japonês em 1930. A conquista da Manchúria em 1931 marca a grande expansão nipônica que irá resultar na entrada do Japão na $2^{2}$ Guerra Mundial.

is As nações européias vão se afastando uma das outras em razão do nacionalismo econômico, e a política armamentista como alternativa à estagnação industrial e ao desemprego vai ganhando espaço nos paises. As diferenças entre as grandes potências também dividiam os Estados em ricos e $\mathrm{cm}$ insatisfeitos. Estados Únidos da América, França c Inglaterra, detentores de $80 \%$ do ouro mundial e de grandes reservas de divisas. exerciam também significativa influência $\mathrm{cm}$ regiōes da América Latina. Ásia e África, o que permitiu a esses paises afrontarem a crise em melhores condições. Jả a Alemanha, ttália e Japão, desprovidos de ouro e divisas e vendo restrito os créditos estrangeiros, encontravam-se paralisados. 
A Segunda Grande Guerra se inicia em 1939 com operações militares isoladas e aparentemente sem qualquer propósito. Em pouquíssimas semanas, a partir de $1^{\circ}$ de setembro, a Polônia caiu sob domínio alemão. Os soviéticos, em 18 de setembro, penetram nos territórios que lhe foram cedidos no então recente acordo com os alemães. O que se viu no inverno de 1939 a 1940 foi as potências procurarem aumentar suas influências sobre zonas estratégicas economicamente.

No final de maio de 1940, as panzerdivisionen, regimentos mecanizados alemães, abrem ofensivas sobre a França, ao norte e ao sul. Com a derrota dos franceses a Inglaterra se viu isolada na guerra contra Alemanha e Itália. O presidente dos EUA, Roosevelt, persuadido de que uma vitória do Eixo comprometeria os interesses norteamericanos, assina com Churchill a Carta do Atlântico, selando a solidariedade entre as potências anglo-saxônicas e estabelecendo os princípios que reorganizaria o mundo pósguerra.

Apesar das diversas conquistas do Eixo e de seu esforço diante das outras nações, em 1943 o equilibrio de forças começa a dar sinais de estar diferenciado e a superioridade material dos aliados garantiu-Ihes o dominio decisivo na evolução do conflito. Em maio de 1945 a Segunda Guerra Mundial se encerra na Europa, e em agosto na Ásia, com resultados catastróficos, números bem mais impressionantes do que os da Primeira Guerra. ${ }^{16}$

Encerrada a Segunda Guerra, as antigas potências, Inglaterra, França, Alemanha e Japão, estavam restritas a um papel secundário, tendo o cenário mundial apenas duas grandes potencias, EUA e URSS, em tomo das quais se agrupavam os demais paises; iniciava-se outra guerra, a Guerra Fria.

Exigiam, então, como condição mínima de sobrevivência nacional, o acesso às matérias-primas e aos mercados, bem como direito às colônias e às zonas de influência econômica. Em 1938, as indecisões e as divisões entre os paises europeus contribuiram para as iniciativas nazistas, que passaram a dominar as relaçōes internacionais. A Inglaterra, por exemplo, não enxergava nas questōes da Europa Central problemas essenciais à sua segurança nacional, e defendia uma politica de apaziguamento. A França, por outro lado, com iniciativas imprecisas face ao temor alemão não representava obstáculos ao Reich. A URSS até que tentou cooperar com a Liga das Nações, mas percebeu que estava isolada já que a segurança coletiva era pouco provável face às indecisões inglesas e francesas. Os Estados Unidos da América defendiam o seu isolacionismo. tanto que em 1937 são votadas no Senado leis de neutralidade, que proibiam a venda de armamentos aos paises beligerantes.

in As perdas humanas ultrapassaram cinqüenta milhões, e os bombardeamentos destruiram instalaçōes industriais, meios de comunicação. portos, ferrovias e rodovias. Os Estados europeus estavam endividados e suas moedas sofrendo forte inflação. Os ELA, por outro lado, apesar dos 300 bilhões de dólares gastos no conflito tiveram um aumento de sua produção industrial de $75 \%$ e passaram a deter $80 \%$ do ouro mundial. O presidente norte-americano Truman lidera um plano de reconstrução da Europa (Plano Marshall) e de bloqueio ao avanço do comunismo (Doutrina Truman), também para evitar que a superprodução associada a provável falta de consumo conduzissem a um desequilibrio econômico semelhante ao da crise de 1929 (politica do Fair Deal, continuaçāo do New Deal). 
Interessante notar que no campo da intervenção do Estado (no caso dos vencedores) no domínio econômico, os países signatários do Tratado de Potsdam, ${ }^{17}$ EUA. URSS, França e Inglaterra, receosos de qualquer outra ameaça germânica, adotam a política de descartelização da economia da Alemanha, rompendo as estruturas de seus principais grupos empresariais, tais como IG Farben, Bayer, Hoechst e BASF, que tinham atuação em diversos setores da economia, como carvão, ferro, químico, plásticos, engenharia pesada, bancos, dentre outros. ${ }^{18}$

A Guerra Fria entre os blocos capitalista e socialista persiste até o final da década de 1980, quando o presidente dos EUA, Ronald Reagan, já no final de seu mandato, intensifica entendimentos com o presidente soviético. Mikhail Gorbatchev, resultando em profundas transformações no mundo socialista. Além de representarem o fim da Guerra Fria, tais mudanças no cenário global confirmaram os EUA como grande potência mundial.

O Japão, por sua vez, representou para os EUA a contenção do socialismo no Extremo Oriente, e nos anos 90 os nipônicos concretizavam sua hegemonia econômica na Bacia do Pacífico.

A Europa, ciente de que havia perdido a hegemonia mundial, viu em acordos supra-nacionais a alternativa para alcançar uma reaproximação entre os países e a possibilidade da recuperação política e econômica, daí o surgimento e consolidação da União Européia.

É. portanto, no séc. XX com o Pós-Guerra ( $2^{\text {a }}$ Guerra Mundial), que se tem a consolidação da atuação jurídica do Estado na economia com a confirmação de um novo Direito que se faz presente na maioria das cartas constitucionais que seguem a da República de Weimar. ${ }^{19}$ Verifica-se, então, o Direito Econômico como instrumento

1. Em Potsdam, Berlim, no ano de 1945, reuniram-se pela terceira vez EUA, Inglaterra e URSS para discutirem o pós-Guerra.

18 Segundo ensina Calixto Salomão Filho, “... Na prática. houve só um verdadeiro caso de Iracionamento industrial, o do IG Farben Konzem. Altamente envolvido e comprometido com o esfurço bélico alemão, esse conglomerado, formado por empresas que iam do setor siderúrgico ao químico, exatamente pela variedade das áreas em que estava envolvido, foi facilmente fragmentado, originando empresas yue eram monopolistas em suas áreas, Höechst, Bayer e BASF" SALOMÃO FILHO, Calixto. Direito concorrencial: as estruturas. São Paulo: Malheiros, 1998. p. 336.

19 Nesse sentido, escreve Joào Bosco Leopoldino da Fonseca: “... O Estado tinha de se valer de instrumentos juridicos adequados para, por seu intermédio, dirigir a nova ordem que se impunha de modo critico c que exigia tratamento adequado. Vê-se, a partir daí, que o Estado tinha de intervir na economia. O Tistado não podia mais permitir que a crença na ordem natural da economia dirigisse os fenômenos econômicos" FUNSE( 'A, João Bosco Leopoldino da. Direiro Económico. 4. ed. rev. e atual. Rio de Janeiro: Forense. 200I. p. 09 
jurídico a dar segurança à práticas econômicas, garantindo a atuação do Estado e assegurando a ordem econômica e social. ${ }^{20}$

Interessante observar, que é possivel verificar a necessidade do Direito Econômico na obra de Max Weber, Economia e Sociedade. A partir da análise da "ordem jurídica" e da "ordem econômica" Weber assinala que:

... a 'ordem jurídica' ideal da teoria do direito não tem diretamente nada a ver com o cosmos das ações econômicas efetivas, uma vez que ambos se encontram em planos diferentes: a primeira, no plano ideal de vigência pretendia: o segundo. no dos acontecimentos reais. Quando. apesar disso, a ordem econômica e a jurídica estão numa relação bastante intima, é porque esta última é entendida não em seu sentido juridico, mas no sociológico: como vigência empirica. O sentido da palavra ordem jurídica' muda então completamente. Não significa um cosmos de normas interpretáveis como logicamente 'corretas' mas um complexo de motivos efetivos que determinam as ações humanas reais. Cabe interpretar isso em seus detalhes. ${ }^{21}$

Tem-se, portanto, uma nova fase do mundo jurídico-econômico e social, com a implementação de novas realidades e disciplinas juridicas a partir do Direito Econômico, tais como a implementação de Blocos Econômicos, o Direito do Consumidor, Direito Ambiental, Direito da Concorrência, Agências Reguladoras e uma nova forma de se preocupar e controlar o abuso do Poder Econômico.

Nesse sentido, conclui-se com o entendimento de Max Weber, segundo o qual: “... o funcionamento de uma ordem econômica do tipo moderno não é possivel sem uma ordem jurídica de caráter muito especial, a qual, na prática, só pode ser uma ordem 'estatal'" 22

20 De acordo com a conceituação de Washington Pèluso Albino de Souza: "Direito Económico è o ramo do Direito que tem por objeto a 'juridicização' ou seja, o tratamento jurídico da política econômica e, por sujeito, o agente que dela participe. Como tal, é o conjunto de normas de conteúdo econômico que assegura a defesa e harmonia dos interesses individuais e coletivos, de acordo com a ideologia adotada na ordem jurídica. Para tanto, utiliza-se do "principio da economicidade"" SOUZA, Washington Peluso Albino de. Primeiras linhas de direito econômico. 5. ed. São Paulo: LTr, 2003. p. 23.

21 WEBER, Max. Ecunomia e sociedade, cit., p. 209 e 210.

22 Id. Ibid., p. 226. 


\section{Direito Econômico e Poder}

Para iniciar a análise do Direito Econômico e Poder, pautado em sua análise jusfilosófica, interessante verificar o que é o Poder, que segundo Abraham Kaplan e Harold Lasswell: “... é um valor de deferência que interessa particularmente à ciência política; ele pode ser descrito em termos de seu domínio, alcance, peso e coercitividade. Pode distinguir-se formas de poder conforme o valor sobre o qual o poder está baseado. Também se classificam relações de influências para as quais o poder é uma base" $23^{23}$

Dentre as formas do poder manifestar-se, tem-se o poder econômico, conforme a explicação de Abraham Kaplan e Harold Lasswell:

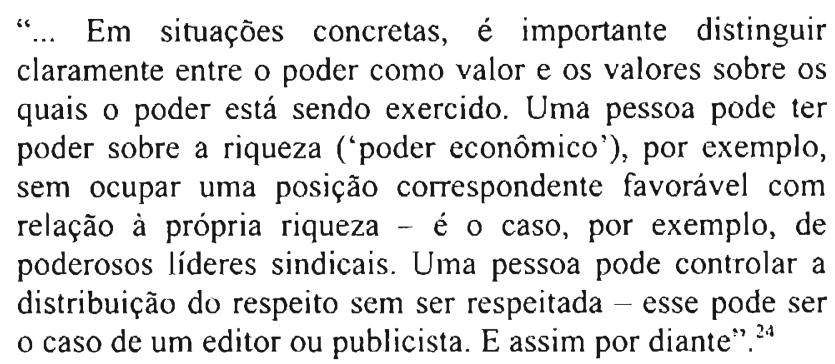

No contexto do econômico como valor do poder, e para o entendimento acerca do poder econômico, assinala Max Weber que “... a troca é a forma especificamente pacifica de obter poder econômico" ${ }^{25}$ Nesse sentido, pode-se verificar da leitura de Hannah Arendt, quando a relação humana passa a ser regida pela relação de troca de produtos, o cenário passa a ser o mercado, aparecendo o elemento do poder econômico.

Hannah Arendt assinala que: "o poder, segundo Hohbes, é o controle que permite estabelecer os preços e regular a oferta e a procura de modo que sejam vantajosas a quem detém este poder" ${ }^{26}$

23 KAPLAN, Abraham; LASSWELL, Harold. Poder e sociedade. Brasilia: UNB, p. 109.

24. Id. lbid., p. 112.

$\because \quad$ WEBER, Max. Economia e Sociedade,cit., p. 422.

26 ARENDT, HANNAH. Origens do Tolalitarismo: Anti-semitismo. Imperialismo, Totalitarismo. São Paulo: Companhia das Letras, 2004. p. 169. 
Em uma economia de mercado, ${ }^{27}$ na qual estão envolvidos diversos relacionamentos econômicos (trocas), a concorrência é algo fundamental, uma vez que ela além de possibilitar uma maior variedade de produtos e o aprimoramento na qualidade dos mesmos, contribui diretamente para a redução de preços. A concorrência se revela a essência da relação de equilíbrio entre a oferta e a procura.

Entretanto, a ausência do Estado no domínio econômico para fiscalizar e regular a livre iniciativa dos agentes econômicos na defesa da concorrência, ou a relação que se estabelece entre o Poder Público e o Privado, implicam no incremento dos monopólios capitalistas, "... conquistados no mercado em virtude do poder de propriedade" 28

\subsection{Poder Econômico e Mercado}

Ao analisar "o mercado" em seu capítulo VI (inacabado), de Economia e Sociedade, Max Weber escreve que: “... Falamos de mercado quando pelo menos por um lado há uma pluralidade de interessados que competem por oportunidades de troca" 29

A auto-regulação do mercado pela mão invisivel da concorrência regida pela lei da oferta e da procura, como defendeu Adam Smith, representa o ideal da matéria concorrencial. Contudo, a história já mostrou que a ordem econômica não consegue se auto-controlar com os agentes econômicos atuando num mercado sem a fiscalização e disciplina do Estado.

Neste sentido, observa Max Weber que:

... Os interessados em sentido capitalista continuam desejando a crescente ampliação do livre mercado até que alguns deles se arriscam, mediante a compra de privilégios do poder político ou simplesmente graças à força de seu próprio capital, a conquistar monopólios para a venda de seus produtos ou para a obtenção de seus meios de produção materiais, fechando então, por sua vez, o mercado. ${ }^{30}$

27 Ensina Washington Peluso Albino de Souza que: "Tomou-se expressāo corrente a 'economia de mercado" A lastando-se do sentido mais genérico e originário. de "local considerado em que se verifica a circulaçào da riqueza, isto $\dot{e}$, dos 'bens', sob a forma de 'produtos também denominados mercadorias' e dos 'serviços", 'capitais" e assim por diantc. tcmos a expressão no seu significado atual. chamada economia de mercado" "SOUZA. Washington Peluso Albino de. Primeiras linhas de direilo económico. 5. ed. São Paulo: LTr, 2003. p.492.

28 WEBER. Max. Economica socicdade, cit., p. 421.

29. Id. lbid., p. 419 .

30 Id. Ibid.. p. 421. 
O dever de defender a concorrência é exercido pelo Estado por meio de seus órgãos competentes, impondo-se a todos os agentes econômicos atuantes no mercado, independentemente de serem entes privados ou estatais desempenhando atividade econômica.

Para a teoria neoclássica, sobretudo, o poder econômico no mercado se traduziria na possibilidade do agente detentor desse poder reduzir a oferta de produtos ou serviços e conseqüentemente aumentar seus preços. Porém, essa teoria tem forte influência do consumer wellfare (bem-estar do consumidor), e pode acabar ocultando o abuso do poder econômico nos mercado que se daria por forma outra.

Por essa razão, a condição de aumentar preços não exprime necessariamente a existência do poder econômico no mercado. Um agente econômico pode muito bem exercer seu poder no mercado, e até mesmo abusar dele por outros meios. Por exemplo: admitindo uma menor lucratividade, mas com uma grande participação no mercado; ou obtendo uma maior lucratividade, mas com uma participação de mercado mais reduzida. Ou seja, um agente econômico "eficiente" e em condição de reduzir seus preços em relação aos seus concorrentes e mesmo assim auferir lucro, mesmo que menor; ou esse mesmo agente aumentar seus preços e auferir um lucro maior, mas com uma perda de participação de mercado. Em ambos os casos o poder no mercado estaria expresso.

Merece destacar que nessas ocorrências o poder de mercado não se relaciona necessariamente e diretamente com o market share detido pelo agente econômico, visto que sua capacidade de aumentar preços "pode" ser limitada pelas condições dos compradores optarem por outros sucedâneos ou pelo ingresso no mercado de outros agentes econômicos, o que aumentaria a concorrência.

As barreiras à entrada, ${ }^{31}$ conceito de grande importância para a análise do exercício de poder no mercado de um agente econômico, diz respeito a possível obtenção pelo agente de lucros de monopolista sem que novos competidores vislumbrem sua entrada nesse mercado, apesar de atraídos por tais lucros.

$\mathrm{O}$ desestímulo ao ingresso dos novos entrantes se daria pelas barreiras $\dot{a}$ entrada, fatores existentes num mercado que colocam um potencial concorrente em desvantagem em relação aos agentes econômicos já estabelecidos, dentre os quais podese citar: (i) custos fixos elevados; (ii) custos irrecuperáveis ou afundados (sunk costs);

31 Na definição de Alberto Pera, secretário geral de 1990 a 2000 da Autorilà Garante dello Concorrenza e del Mercato (AGCM), órgão antitruste italiano: "Le 'barriere all'entrata ciné i costi addizionali rispello alle imprese già stabilite sul mercato che i nuovi entrunti dovranno sopportare, rapresentano il principale limire alla 'concorrenza potenziale ". PERA, Alberto. Concorrenza e Antitrist. 2. ed. Bologna: il Mulino. 2001. p. 30 e 31. 
(iii) barreiras legais ou regulatórias; (iv) recursos de propriedade das empresas instaladas; (v) economias de escala ou de escopo; (vi) grau de integração da cadeia produtiva; (vii) fidelidade dos consumidores às marcas: e (viii) a ameaça de reação dos competidores instalados.

Observa-se, então, que se trata de um poder relativo e não absoluto. que consiste substancialmente na possibilidade do agente econômico reduzir a quantidade de produção e aumentar o preço. sem que concorrentes a curto tempo ingressem no mercado para satisfazer a demanda com preços inferiores. Lembramos que tal condição não se relaciona necessariamente com a posição do agente no mercado ou com a sua complexa potência econômica. A finalidade da defesa da concorrência é a de garantir o bom funcionamento do mercado.

O funcionamento do mercado, tutelado por uma eficaz legislação de defesa da concorrência, impõe um limite a possibilidade dos agentes adquirirem poder econômico por meio de comportamentos e práticas restritivas, ao invés da eficiência e de suas capacidades superiores. Neste ponto, a participação de mercado e o poder econômico não são per se negativos, mas podem, ao contrário, possibilitar a utilização de capacidade técnica ou organizacional que não estaria disponível a empresas de menor porte, com benefĩcios aos consumidores e até mesmo a economia. ${ }^{32}$

Todavia, a essência da legislação de defesa da concorrência está na confiança de que se o mercado é operante e protegido de práticas anticoncorrenciais será difícil o poder econômico se converter em abuso. Além do mais, num mercado concorrencial dificilmente os agentes econômicos de grande porte e detentores de poder estarão sozinhos. Atuarão nesse mercado outros grandes agentes, como também agentes menores e eficientes. Com isso, o abuso individual do agente detentor de poder econômico será mais difícil de ocorrer.

\subsection{Controle do Poder Econômico e Democracia}

A análise do Poder Econômico e Democracia, leva seu pesquisador a interpretar se o "poder econômico" em si é algo antijurídico. Á luz da ordem constitucional, verifica-se o contrário, ou seja, nada se tem contra o poder econômico, mas sim quando ele é utilizado de forma abusiva.

Para uma análise mais aprofundada, recomenda-se a leitura do item VII. Conceito de Poder Fconômico e seu Abuso; VII. I. Poder Econômico (Poder de Mercado) e Posição Dominante (participação de Mercado): Distinção; e VII.2. U Poder F.conômico no Mercado e seus Reflexos na Concorréncia, itens do livro BAGNOLI, Vicente. Introdução ao direiro da concorréncia: Brasil-Globalização-Linião EuropćiaMercosul-ALCA. São Paulo: Singular. 2005. p. 148-153. 
A Constituição Federal, de 1988, como a maioria das cartas que seguem a da República de Weimar, influenciada por sua vez por dois acontecimentos de 1917 Constituição Mexicana e Revolução Russa, tem em seu corpo a preocupação com o econômico e o social, elevando esses dois conceitos a preceitos constitucionais observados e garantidos pelo Estado.

Ao ocupar-se da economia e do social, o Estado também revela tratar tais princípios de verdadeiro exercício da democracia. Nesse sentido, escreve Celso Lafer:

... os valores fundantes da democracia provêm de $u$ um processo histórico incessante de integração de valores de convivência'. composto de vários legados.

São eles: (...) IV) o legado do libcralismo, ou seja, a noção de Estado de Direito, na qual, graças ao constitucionalismo. a prudente distribuição de competências no âmbito do Estado enseja a fiscalização dos atos do Executivo. que evita o abuso do poder: e, finalmente, V) o legado do socialismo, do qual se origina uma exigência de igualdade perante a vida e a cultura, entendida como direito reconhecido a cada homem de participar do 'hem-estar social' daquilo que a espécie humana, num processo coletivo, vai acumulando através do tempo."

No art. $5^{\circ}$ da Constituição Federal de 1988, observa-se direitos à igualdade, segurança e propriedade. sem os quais uma economia de mercado não conseguiria prosperar, e nos incisos XXIX e XXXIl desse mesmo artigo a garantia do direito de inventos industriais, marcas, nomes e signos distintivos em vista do desenvolvimento tecnológico e econômico do país, bem como a promoção da defesa do consumidor. Nos arts. $6^{\circ} 7^{\circ}, 8^{\circ}, 9^{\circ}, 10$ e 11 , estão disciplinados os direitos dos trabalhadores.

Já o art. 21 dispõe em seus incisos a competência da União que, dentre outras, deverá elaborar e executar planos nacionais e regionais de ordenação do território e de desenvolvimento econômico e social, e explorar, diretamente ou mediante autorização, concessão ou permissão, determinados serviços. No art. 24 , além da competência da União, são também competentes os Fstados e o Distrito Federal para legislar concorrentemente sobre Direitos Humanos econômico. produção e consumn. responsabilidade por dano ao meio ambiente e ao consumidor.

33 LAFER, Celso. Direito e poder na reflexão de Miguel Reale. In: MIGUEL Reale na UNB. Brasilia: UNB. 1981. p. 61 . 
Mas é no Título VII, Da Ordem Econômica e Financeira, art. $170,{ }^{34}$ que se observa os princípios gerais da atividade econômica. Já a repressão ao abuso do poder econômico está disposta no $\S 4^{\circ}$ do art. $173 .^{35}$

A Carta Constitucional de 1988, portanto, implanta uma nova ordem econômica no cenário nacional, exigindo do Estado e dos agentes econômicos postura inédita para estarem adequados à nova realidade legal, inserida no contexto mundial. ${ }^{26}$ Tal prática, demonstra a preocupação do legislador no controle do poder econômico, a fim de coibir abusos, para o pleno exercício da democracia.

\subsection{Relação do Poder Econômico e Político: captura}

O poder econômico muitas vezes mantém uma estreita ligação com o poder político. Essa relação imbricada pode resultar em leis (legitimações de poder) que muitas vezes atendem aos interesses de uma minoria detentora de poder econômico, em prejuízo aos anseios da maioria, da coletividade.

Escreve Norberto Bobbio que:

Questa corrispondenza tra i problemi della ginstificazione del potere e quelli della giustificazione della norma giuridica non costituisce uma sorpresa per chi consideri che il potere e la norma sono due facce della stessa medaglia. Il potere nasce da norme e produce norme; la norma nasce dal potere e produce altri poteri. ${ }^{37}$

A relação descrita por Bobbio do poder e da norma, revela que o poder pode influenciar o nascimento da lei e essa lei produzir outros poderes. Muitas ć o poder econômico que influencia a criação da norma para o benefício dos detentores desse poder.

Nesse sentido, com muita propriedade Fábio Nusdeo trata da "Aplicação da Legislação Econômica: As Agências e o Processo de Votação" capítulo III de sua tese apresentada em 1993 à Faculdade de Direito da Universidade de São Paulo para

34 Diz o art. 170 da Constituição Federal: "A ordem econômica, fundada na valorização do trabalho humano e na livre iniciativa, tem por fim assegurar a todos existência digna, conforme os ditames da justiça social. observados os seguintes principios: ..."

35 “Art. 173 (...) $\S 4^{\circ}$ - A Lci reprimirá o abuso do poder económico que vise à dominação dos mercados, à eliminação da concorrência e ao aumento arbitrário dos lucros"

36 Neste sentido, escreve Eros Robertu Grau: "Que a nossa Constituição de 1988 é uma Constituição dirigente, isso é inquestionável. $O$ conjunto de dirctrizes. programas e fins que enuncia. a serem pelo Estado e pela sociedade realizados. a ela confere o caráter de plano global normativo. do Fstado e da sociedade. O seu art. 170 prospera, evidenciadamente, no sentido de implantar uma nova ordem econômica" GRAU, Eros Roberto. A ordem econónica na Constituição de 1988. 8. ed. São Paulo: Malheiros, 2003.p. 153. (itálico no original)

37 BOBBIO. Norberto. Sudi per una Teoria Generale del Diritlo. Torino: Giappichelli. 1970. p. 86. 
Concurso de provimento de cargo de Professor Titular do Departamento de Direito Econômico e Financeiro, abordando a obra de Dows An Economic Theory of Democracy:

... Parte ele do pressuposto de uma postura coerente entre o setor público e o setor privado da economia, ou seja, da mesma forma que os operadores privados tentam maximizar os resultados de sua atividade no mercado, os operadores públicos, administradores das agências governamentais, basicamente, também procuram maximizar algum ou vários elementos que para eles se revestem de grande valor, como, por exemplo, o grau de probabilidade de se manterem no cargo - eletivo ou burocrático -, a influência, o prestigio, a popularidade e outros do gênero. Nessas condiçōes, aquele operador público poderá ser levado a tomar decisões favorecedoras de uma minoria e não da maioria, como seria de se esperar. Isso poderá ocorrer quando, exemplificativamente, duas proposiçôes diversas forem apoiadas com grande empenho por dois grupos em cada caso minuritários e encontrarem oposição, porém pouco coesa, por parte de uma maioria menos combativa. ${ }^{38}$

A observação de Fábio Nusdeo insere-se no contexto da análise da Escola da Public Choice para a teoria do funcionamento das agências governamentais, segunda a qual: “... dar-se-ia a captura da agência já no seu nascedouro, no momento mesmo da sua criação, pois esta teria por escopo muito mais o atendimento dos interesses do setor a ser regulado pela agência em questão do que a defesa do interesse público ou outras finalidudes de alcance mais geral" 39

Entretanto, pode-se estender a chamada teria da cooptação ou da captura, para o relacionamento que se dá entre o poder econômico (privado) e o poder público (Estado) no próprio processo legislativo e na seara do executivo. Da mesma forma que os funcionários das agências podem ser capturados pelo poder privado, o político para manter-se no poder (ou o seu partido) pode ser cooptado pelos interesses do poder econômico privado, ainda que em prejuizo da coletividade.

38 NUSDEO, Fábio. Fundamentos para uma L'odificaçâo do Direito Econômico. tese apresentada em 1993 à Faculdade de Direito da Universidade de São Paulo para Concurso de provimento de cargo de Professor Titular do Departamento de Direito Econômico e Financeiro, p. 96 e 97.

39 NUSDEO, Fábio. Fundamentos para uma Codificação do Direito Econômico tese apresentada em 1993 à Faculdade de Direito da Universidade de São Paulo para Concurso de provimento de cargo de Professor Tirular do Departamento de Direito Económico e Financeiro, p. 93. 


\subsection{Poder Econômico: Relação Público e Privado (organograma)}

A relação entre o público e privado na esfera do poder econômico, ocorre por meio de troca de interesses. Tal prática, entretanto, não é um fato atual, pelo contrário, a história revela que essa relação imbricada data de longa data, por exemplo, das concessões que o Estado Absolutista fazia a particulares para a exploração de monopólios mediante pagamento de taxas. Outrossim, a Revolução Gloriosa explicita a sustentação da monarquia constitucional pela burguesia, ao passo que o monarca daria segurança jurídica para o burguês realizar seu comércio. O próprio Napoleão, ápice da Revolução Francesa, revela a expansão das fronteiras (e dos mercados) como a constituição de um Império e de oportunidades para a classe burguesa.

É verdade, também, que o Estado Democrático de Direito tenta coibir abusos, por meios de mecanismos que limitam o abuso do poder, utilizando-se de freios e contra-pesos (check and balances).

Diante disso, e de todo o exposto até o momento, conclui-se essa parte do trabalho com a apresentação do seguinte organograma, que demonstra o entendimento aqui apresentado.

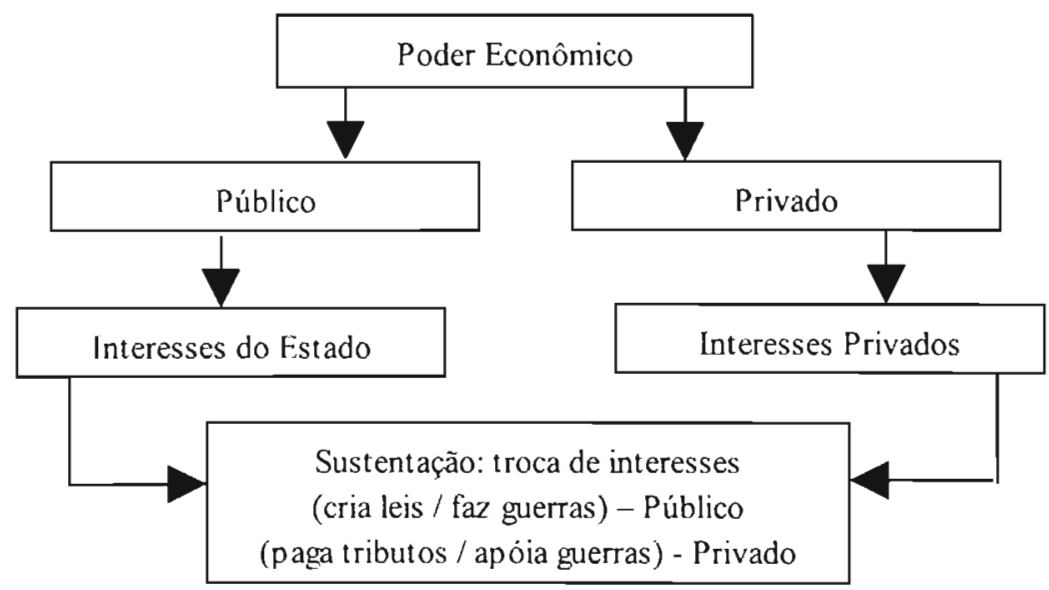




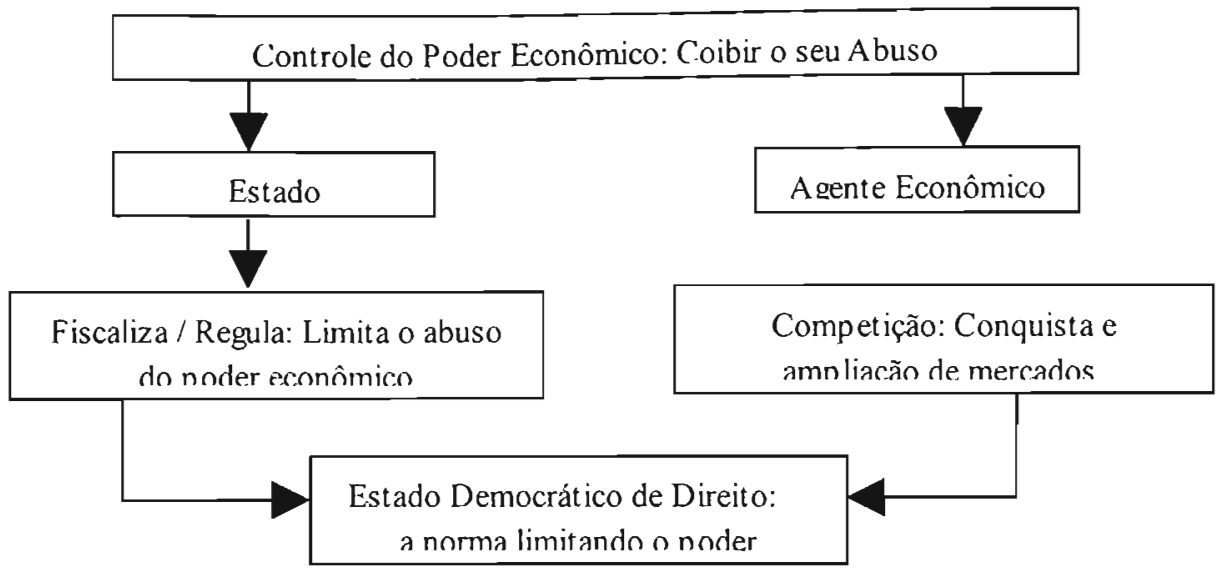

\section{Poder Econômico e Imperialismo}

No horizonte filosófico do Direito e da História, verifica-se a relação existente entre o Poder Econômico Privado e o Imperialismo, numa verdadeira troca de interesses entre governo (poder político Estatal) e agentes econômicos (poder privado - particulares). Hannah Arendt procede essa análise à luz do Leviatã de Hobbes:

... Hobbes é, realmente, o único grande filósofo de que a burguesia pode, com direito e exclusividade, se orgulhar, embora os seus princípios não fossem reconhecidos pela classe burguesa durante muito tempo. O Leviathan de Hobbes expôs a única teoria política segundo a qual o Estado não se baseia em nenhum tipo de lei construtiva seja divina, seja natural, seja contrato social - que determine o que é certo ou errado no interesse individual com relação às coisas públicas. mas sim nos próprios interesses individuais, de modo que ${ }^{\circ} \mathrm{o}$ interesse privado e $\mathrm{o}$ interesse público são a mesma coisa ${ }^{40}$

Tal relação que data de séculos, destaca-se mais recentemente com a consolidação de um novo Império, o Império do século $\mathrm{XX}$, os Estados Unidos da América.

Após abordar, ainda que brevemente, a manifestação do Poder Fconômico no decorrer da História do Capitalismo e tratar do Direito Econômico e Poder nos aspectos do Poder Econômico e Mercado, Controle do Poder Econômico e Democracia, Relação do Poder Econômico e Político: captura e o Poder Econômico: Relação Público

tu ARENDT, Hannah. Urigens do Totalitarismo: Anti-semitismo, Imperialismo, Totalitarismo. São Paulo: Companhia das Letras, 2004. p. 168-169. 
e Privado, entende-se já haver subsídios necessários para concluir essa breve abordagem acerca do Poder Econômico e Imperialismo: A Relação entre Público e Privado.

\subsection{Impérios, Poder e Soberania}

A História Universal apresenta a existência de povos dominantes e povos dominados, mais que isso a existência de Impérios que em dados momentos se constituem e exercem por certo período sua dominação em relação aos Estados subordinados, tal qual a relação entre o senhor e o escravo.

Muitas vezes a subordinação é facilmente percebida e até mesmo contestada, já em outros casos o imperialismo se dá de forma velada e ainda mais proveitosa para o Império.

Nesse sentido, pertinente a análise de Tércio Sampaio Ferraz Junior acerca da fenomenologia do poder, segundo o qual: “... O poder que não é percebido é, de todos, o mais perfeito: aquele cujo processo chegou a um fim; alter e ego, dominante e dominado, são um só, embora continuem como se fossem distintos" $41 / 42$

O Império Oriental, o Império Grego, o Império Romano e o Império Germânico, como retratados por Georg Wilhelm Friedrich Hegel em Principios da Filosofía do Direito ${ }^{43}$ e Filosofia da História, ${ }^{44}$ e ainda os Impérios Francês e Inglês, ${ }^{45}$ além do que se ousa chamar desde já Império dos Estados Unidos da América, ${ }^{46}$ revelam que as relações entre o Estado detentor do poder de Império com os demais Estados não são de cunho filantrópico (pensamento universal), mas sim de interesses próprios, como se fossem entes particulares. ${ }^{47}$

* FERRAZ JNIOR, Tércio Sampaio. Estudos de Filosofía do Direito: Reflexões sobre o Poder, a Liberdade, a Justiça e o Direito. São Paulo: Allas. 2002. p. 15.

42 Nesse sentido, convém citar trecho de Norberto Bobbio, segundo o qual: "... Uma das principais tarefas da teoria económica do imperialismo depois da Segunda Guerra Mundial e do rápido processo de descolonização é exatamente analisar e explicar as novas formas de dominio nas relações internacionais que nada têm a ver com relações tradicionais fundadas principalmente na força militar" BOBBIO, Norberto. Teoria Geral da Política: A filosofia politica e as lições dos clássicos. Rio de Janeiro: Campus, 2000. p. 551.

43 HEGEL, Georg Wilhelm Friedrich. Principios da Filosofia do Direitn. São Paulo: Martins Fontes, 2000.

4 Id. Filosofía da História. 2. ed. Brasilia: UNB, 1999.

ss Eric J. Hobsbawn escreve que: “... Em primeiro lugar, a Grã-Bretanha desenvolveu-se como parte essencial de uma economia global, e, mais particularmente, como centro daquele vasto "império" formal ou informal, sobre o qual seu destino repousou em alto grau". HOBSBAWN, Eric. Da Revolução Industrial Inglesa an Imperialismo. 5. ed. Rio de Janeiro: Forense Universitário, 2003. p.19

t*a O Imperialismo Norte-Americano, ainda que não pormenorizado, será abordado no próximo item deste trabalho.

47 Escreve G. W. F. Hegel: "Nas relaçōes entrc si, os Estados comportam-se como particulares. Têm elas, por conscguinte, aquilo que há de mais mutável na particularidade, nas paixỏes, interesses, finalidades, talentos. virtudes, violências. injustiças e vícios, mas elevado à mais alta potência que possa assumir. Trata-se de um jugo em que o próprio organismo moral, a independência do Estado estão expostos ao 
A atuação do Império como "agente privado", pode ser compreendida a partir da estreita relação entre Estado e capital privado. Conforme se depreende da leitura de Economia e Sociedade de Max Weber, ${ }^{48}$ em diversos casos de codificação, dificilmente devem ter interferido de modo direto interesses econômicos de pessoas privadas. Ao contrário, precisamente o mais antigo exemplar, relativamente completo e singular em sua forma de todas as codificações conservadas, o Código de Hamurabi. permite com alguma probabilidade concluir que existia uma camada relativamente forte de interessados na troca de bens e que o rei, em seu próprio interesse político e fiscal, desejava dar apoio à segurança jurídica desse comércio.

Weber também aponta que os conflitos existentes são em grande parte conseqüência inevitável de ser a legalidade intrínseca à lógica de todo o pensamento jurídico formal inconciliável com as ações juridicamente relevantes dos interessados e com seus acordos, fechados para obter efeitos econômicos e orientados em expectativas economicamente qualificadas. Ora, trazendo esses entendimentos à realidade de análise filosófica da conjuntura sócio-econômica do Imperialismo, deve-se fazer um estudo atento acerca desta realidade.

Para o empresário investir no país, ele exige, além da estabilidade monetária e um mercado consumidor (ou que sirva como centro exportador), a segurança jurídica para produzir e comercializar o seu produto, inclusive com o combate aos abusos que possam ocorrer dentro de um mercado concorrencial. O poder econômico acaba influenciando o Governo a adotar certas normas legais e econômicas favoráveis aos interesses das empresas, que acabam permitindo uma arrecadação interessante para o Estado, além de beneficiá-lo pela conquista do apoio político, determinante para sua manutenção (ou de seu partido) no poder.

Percebe-se da lição de Weber que o interesse político e físcal do governante acaba por atender aos interesses dos empresários, situação que é favorável a ambos. Entretanto, quando esses interessados privados decorrem de instituições cuja sua sede encontram-se no Império, os Estados podem acabar por sujeitarem-se aos mandos do Império que atua em causa própria, ou seja, na própria defesa do interesse dos seus entes particulares que estão associados ao Estado, ao Império, constituindo algo único.

acaso. Os princípios do espirito de cada povo ficam essencialmente limitados à causa da particularidade $\mathrm{em}$ que possuem a sua objetiva realidade e a consciência de si enquanto individuos existentes. Por isso os seus destinos, os seus atos nas reciprocas relações constituem a manifestação fenomênica da dialética destes espiritos enquanto finitos. É em tal dialética que se produz o espírito universal, o espirito do mundo enquanto ilimitado, e é ele que exerce, ao mesmo tempo, sobre esses espiritos o seu direito (que é o direito supremo) na história do mundo como tribunal do mundo" HEGEL, Georg Wilhelm Friedrich. Principios da Filosofia do Direito. São Paulo: Martins Fontes. 2000. p. 306-307.

48 WEBER. Max. Economia é sociedade, cit. 
A temática da soberania ganha destaque, pois será que o Estado que se subordina ao Império é de fato soberano em todos os aspectos? Mais que isso, pode-se entender a soberania como algo fragmentado ou é ela indivisivel? ${ }^{4 y}$

Desde a Antigüidade a doutrina da soberania é abordada nos pensamentos políticos, teológicos e jurídicos. Na Grécia. Aristóteles definia na "autarquia" grega a polis como a comunidade superior, ideal e suficiente em si mesma. Em Roma o conceito de soberania, apesar de não constar expressamente do Direito Público, ganha ênfase com a outorga das majestas, imperium e potestas ao povo romano. que era representado tanto pelo Príncipe como pelo Senado.

$\mathrm{Na}$ Idade Média prevalece o entendimento da harmonia divina para governar o mundo na união da humanidade, sendo o Imperador a pessoa a ocupar a figura de Cristo (Deus-Homem, concepção cristocêntrica da monarquia). A origem da Igreja e do Império é única, divina, e, portanto, são interdependentes.

Mas é em 1576 com Bodin que se inicia a moderna teoria política, com um conceito de soberania limitável e divisível característico da doutrina jusnaturalista, oposto ao entendimento do médio evo. ${ }^{50}$ A soberania não se traduzia em absolutismo, pois os príncipes subordinavam-se tanto às leis divinas quanto naturais.

No jusnaturalismo moderno dos séculos XVII e XVIII prevalecem os princípios do Direito Natural. Primeiramente interpretando-se a sociedade como sendo anterior ao indivíduo e, na seqüência, Hobbes declarando a anterioridade do indivíduo à sociedade. Daí o contrato entre os indivíduos desagregados para constituir um Estado e um soberano.

Rousseau, retumando idéias da antiguidade e reformulando parte do conceito de Hobbes, ${ }^{5 t}$ concebe o Estado (Leviatã) como o ponto de chegada onde o homem poderia viver eternamente (solução para os problemas da sociedade civil). $O$ princípio da soberania é defendido por Rousseau sob uma óptica revolucionária, em que se aceita um direito de revolução permanente segundo o qual se finda a subordinação à lei quando o povo for soberano.

49 Neste ponto está o problema motivador da pesquisa a ser feita para a tese de Doutorado de Vicente Bagnoli em Filosofia e Teoria Geral do Direito na Faculdade de Direito da Universidade de São Paulo, sob a orientação do Prof. Dr. Ari Marcelo Solon: Os limites juridicos do imperialismo frente aos limites econômicos da soberania.

so Escreve Bodin que: "La soherania no es limitada, ni en poder, ni en responsabilidad. ni em tiempo..." BODIN, Jean. Los Seis Libros de la Republica. Madri: Aguilar, 1973. p. 48.

i) Hannah Arendı escreve que: ... Hobbes confessa orgulhosamente que o Leviatã é realmente um govemo permanente de tirania: a palavra Tirania significa nem mais nem menos que a palavra Soberania. (...) Acho que tolerar o ódio declarado à tirania é tolerar o ódio à comunidade em geral"'. ARENDT. Hanrah. Origens do totalitarismn: Anti-semitismo. Imperialismo. Totalitarismo. São Paulo: Companhia das Letras, 2004. p. 174. 
Kant, na linha rousseauniana, apresenta o princípio da soberania como o poder legislativo que pertence à vontade coletiva do povo. Contudo, as idéias positivistas, com destaque à Gerber, Leband e Jellinek, refutam a definição jusnaturalista de atribuir à um órgão ou pessoa a soberania, para defini-la no Estado, exclusivamente. ${ }^{52}$

Kelsen abordando a temática da soberania a coloca como sendo uma superior ordem da conduta humana. No campo do Estado e do Direito a soberania significaria a interpretação dessas ordens como supremas. Contudo. sob a perspectiva do Direito Internacional, a soberania deixaria de existir diante da comunidade jurídica internacional, tendo validade essa ordem jurídica.

Já Carl Schimtt interpreta cientificamente o Direito, buscando conceituar por meio da análise histórica a soberania. O soberano, numa primeira análise schimttiana, seria aquele que decide em estado de exceção. ${ }^{53}$

Com propriedade, após aprofundada análise do conceito de soberania, ensina Ari Marcelo Solon que: "...Pondo-se de lado os pressupostos de uma teoria normativa, a soberania não é outra coisa senão as diferentes regras constitutivas e fatos institucionais atribuidores das qualidades acima a uma determinada realidade politica" $\$ 4$

O Estado moderno é algo relativamente recente e a soberania em sua concepção também moderna se revela uma exigência política para o exercício do

Acerca da doutrina da soberania do Direitos Humanos, escreve Ari Marcelo Solon que: "O professor holandès Krabbe, em seu livro Die Lehre der Rechtssouveränität sustentou a tese de que não è o Estado. mas sim, o Direito que deveria ser considerado soberano. Ele tentou superar o dualismo apresentado pela doutrina juridica alemã entre o Estado como manifestaçào originária de poder e o Direito como limitação do mesmo. Frente à concepção da soberania do Estado, que vê neste a expressão de um poder natural. criador do Direito e posteriormente a ele submetido enquanto pessoa juridica, Krabbc propôs a noção da soberania do Direito, segundo a qual existiria um único poder jurídico idêntico ao poder do Estado. Mesmo negando uma validade independente do poder do Estado perante o Direito. reconhece depender a construção deste num grau elevado daquele" SOLON, Ari Marcelo. Teoria da soberania como problema da norma juridica e da Decisão. Porto Alegre: Sergio Antonio Fabris Editor, 1997. p. 46.

33 Escreve Gilberto Bercovici: "'Sobcrano é quem decide sobre o estado de exceção' Com esta cèlebre frasc, que inicia seu livro Teologia Politica, Carl Schimitt destacou a soberania como uma função politicamente indispensável para afirmar uma ordem" BERCOVICI, Gilberto. Constituição e estado de exceção permanente: atualidade de Weimar. Rio de Janeiro: Azougue F.ditoral. 2004. p. 65.

S. "Arrancando-se o véu que encobre a vontade, a questão da soberania não é um problema de pressuposiçãu ou hipótese da ciência juridica, mas que demanda uma investigaçăo impirica de determınados fatos. A soberania não é imputação. mas o exercicio de uma força social que obtém obediència às suas prescriçōes. É um problema do ser do Dircitos Humanos. Entrc os critérios empiricos para averiguar se um poder é soberano pode-se incluir algumas qualidades como capacidade de auto-organização, um poder de agir e de se conduzir livremente. Pondo-se de lado os pressupostos de uma teoria normativa. a soberania não é outra coisa senào as diferentes regras constitutivas e fatos institucionais atribuidores das qualidades acima a uma determinada realidade politica. Isto nāo é apenas uma tarefa da sociologia juridica, pois toda esta digressāo surgiu a partir de um problema especifico de teoria do Dircitos Humanos: é possivel identificar juridicamente o poder efetivo?" SOLON, Ari Marcelo. Teoria da soberania como prohlema da norma iuridica e da Decisão. Porto Alegre: Sergio Antonio Fabris Editor. 1997. p. 203 e 204. 
controle num determinado território. Um país soberano, o é, além de outros motivos, quando é independente financeiramente. Um país que depende dos investimentos e empréstimos de outra nação, no caso o Império, será independente para legislar e combater eventuais abusos do poder econômico?

Para tanto, deve-se analisar o imperialismo norte-americano para verificar a real soberania dos Estados subordinados ao Império, e em que medida um Estado pode limitar o poder econômico, ou por outro lado se de fato é o poder econômico que modela o Estado.

Faz-se necessário analisar o sistema hegeliano que tem origem na filosofia grega, no racionalismo cartesiano e atinge sua realização mais completa no idealismo alemão, para constatar na Filosofia da História a afirmação de Hegel, segundo o qual: "A história universal vai do leste para o oeste, pois a Europa é o fim da história universal, e a Ásia é o começo" "s

Depreende-se do entendimento hegeliano que tudo o que ocorresse depois da Europa (fim da história) seria tão somente repetição daquilo já registrado na história. Contudo na leitura da Filosofia da História, constata-se uma aparente contradição de Hegel que escreve:

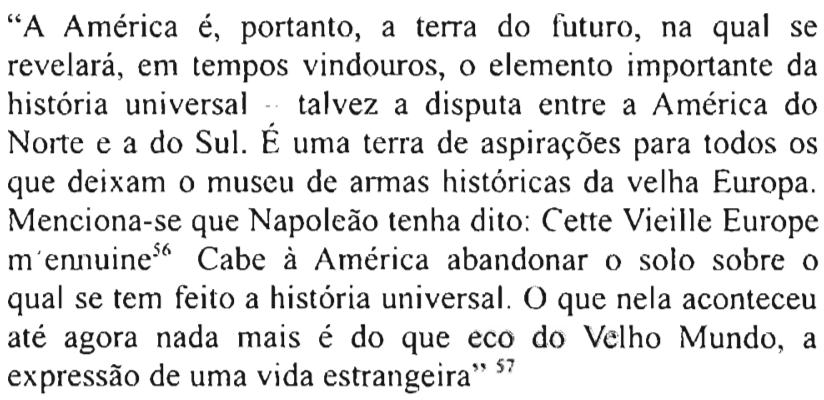

Ainda em Filosofia da História, Hegel escrevendo acerca da história refletida, assinala que esta ultrapassa o presente, não com relação ao tempo, mas sim ao espírito. Para o filósofo alemão, uma modalidade de história refletida é a pragmática, segundo a qual mesmo os acontecimentos sendo diversos, o geral, o essencial, o contexto é único. "Reflexões pragmáticas, por mais abstratas que sejam, são na verdade o presente e vivenciam os relatos do passado para a vida atual" $\varsigma 8$

Conforme iscreveu Hegel:

HEGEL, Georg Wilhelm Friedrich. Filosofia da Hisı́ria. 2. ed. Brasilia: Editora Universidade de Brasilia. 1999. p. 93.

56 Pode-se interpretar a frase de Napoleão como esta cidade européia me entedia.

57 HEGEL, Georg Wilhelm Friedrich. op., cit. p. 79.

s8 Id. Ibid., p. 14. 
... Os destinos dos povos e nações, seus interesses, condições e problemas são outro domínio; predica-se aos governantes, aos estadistas e, principalmente, aos povos instruírem-se por meio da experiência da história. Porém, o que a experiência e a história ensinam é que os povos e os governos jamais aprenderam coisa alguma da história, e não seguiram o ensinamento que ela poderia ter inspirado. ${ }^{59}$

Interpretar os Impérios e o imperialismo a partir da Filosofia da História e do Direito pode ser a maneira de entender a ascensão e declínio de nações dominantes e como os Estados dominados se comportaram no período da dominação. ${ }^{60}$

\subsection{Imperialismo norte-americano}

A leitura da história e o acompanhamento atento ao noticiário revelam que os Estados Unidos da América detêm posição hegemônica e exercem seu imperialismo sem serem fortemente contestados.

Até a realização da soberania imperial norte-americana, uma vez que “... o Império só pode ser concebido como uma república universal, uma rede de poderes e contrapoderes estruturada numa arquitetura ilimitada e inclusiva" 61 a história constitucional dos Estados Unidos da América divide-se em quatro fases ou regimes diferentes, segundo Michael Hardt e Antonio Negri:

... A primeira fase estende-se desde a Declaração de Independência à Guerra Civil e à Reconstrução; a segunda, extremamente contraditória, corresponde à Era Progressista, que abrange a virada do século, da doutrina imperialista de Theodore Roosevelt ao reformismo internacionalista de Woodrow Wilson; uma terceira fase abrange o New Deal, a Segunda Guerra Mundial e vai até o auge da guerra fria; e finalmente uma quarta fase é inaugurada com os movimentos sociais da década de 1960, atravessando a dissolução da União Soviética e do bloco da Europa Oriental. Cada uma dessas fases da História constitucional dos EUA marca um passo rumo à realização da soberania imperial. ${ }^{62}$

Escreve Celso Lafer que: "Os EUA - que pacificamente ganharam a guerra fria - são hoje a linica superpotência mundial. Estão relativamente à vontade

\$9 HEGEL, Georg Wilhelm Friedrich. op. cit., p. 15.

69 Mais que isso, possuiam os Estados meios jurídicos para assegurar sua soburania ou subordinavam-se ao Império? Como se dá o imperialismo nonte-americano? Foi ele revisto, elaborado de forma jamais presenciada pela história? Em caso positivo, qual o meio legal para controlá-lo? Verifica-se. portanto. a necessidade de repensar o poder econômico do Império e a atuação dos Fistados tidos soberanos.

${ }_{61}$ HARDT, Micahel; NEGRI, Antonio. Império. Sào Paulo: Record, 2004. p. 185.

62 Id. ibid., p. 187. 
neste mundo de descontinuidades e vêm explorando as oportunidades que o sistema internacional oferece para unilateralmente, afirmur o seu globalismo no campo estratégico-militar, no econômico-financeiro e no dos valores" " ${ }^{3}$

O modelo norte-Americano que vinha sendo adotado desde o final do séc. XIX, e que se confirma no Pós-Segunda Guerra como Império norte-Americano, tornase único com o colapso da União das Repúblicas Socialistas Soviéticas (URSS).

Trata-se de um novo imperialismo, não mais o da "explosão" de um sistema para a imposição de outro, tal qual registrou-se no passado e mais recentemente na URSS, onde se impunha uma nova cultura (a do dominante) e proibia as tradições dos dominados. O imperialismo norte-americano, aparentemente mais eficiente para o dominador, promove a "implosão" do sistema do dominado, agregando a este os valores culturais e que interessam ao Império. O Imperialismo norte-Americano é o da inclusão do dominado. sob o pretexto de garantir a democracia ao povo dominado. Escreve Michael Hardt e Antonio Negri que:

Essa tendência expansiva democrática, implicita na noção
de rede de poder, precisa ser distinguida de outras formas
de propagação puramente expansionistas e imperialistas. A
diferença fundamental é que a expansividade do conceito
imanente de soberania é inclusivo, não exclusivo. Em
outras palavras, quando se expande, essa nova soberania
não anexa ou destrói os outros poderes que encontra, mas,
pelo contrário, volta-se para eles, incluindo-os na rede. O
que se abre é a base de consenso, e assim, todo o corpo
soberano é continuamente reformado. Justamente por causa
dessa tendência, o novo conceito de soberania é
profundamente reformista.

Tais valores, que interessam aos agentes particulares que atuam em parceria com o Império (poder privado e poder público), propiciam a dominação sóciocultural e econômica. A sincronia entre público e privado para o surgimento do poderio econômico do Império norte-Americano é retratada na obra An Eimpire of Wealth: The Epic History of American Economic Power, de John Steele Gordon. Segundo o autor. diferentemente de outros Impérios, como o Romano ou o Britânico, o grande diferencial dos Estados Únidos da América em relação aos demais países não foi o poderio militar ou político. As razões que transformaram os Estados Unidos da América na superpotência, capaz de exercer sua supremacia em esfera mundial tem sua explicação fundamental na esfera privada. no intenso processo de criação de riqueza, uma história

\footnotetext{
63 LAFER, Celso. A Identidade Internacional do Brasil e a Politica Externa Brasileira: passado, presente e futuro. São Paulo: Perspectiva, 2001. p. 110.

a HARDT, Micaleel; NEGRI, Antonio, cit., p. 186.
} 
de empreendedores, invenções e empresas. que viabilizaram esse processo com o apoio do Estado. ${ }^{65}$

Mas não é só. O imperialismo praticado pelos norte-americanos também está nos recursos financeiros que os países. geralmente os em desenvolvimento, necessitam para implantar suas políticas internas. Explica-se, já que as instituições teoricamente internacionais, são muitas vezes mantidas e controladas pelos Estados Unidos da América.

O Império norte-Americano tem também força militar jamais registrada na história, mas não precisa utilizá-la para exercer seu imperialismo, já que possui meios mais eficientes para impor sua dominação.

Para analisar os Estados Unidos da América como Império, interessante a obra Colossus: the price of America s Empire, de Niall Ferguson. que logo na "orelha" do livro assinala:

Is America nu Empire? Few Americans would say so. Yel never before in the history of the world has one nation been so ahead of all others in its military, economic, cultural and political power: In warfare the United states is close to 'full spectrum dominanci' all over the glohe. Its free market model has left the alternatives for dead. Its popular culture, 10o, has a universal appeal. And its foreign policy now explicilly aims at changing other peoples' regimes and rebuilding their nations. If this isn't an empire. what is it? ${ }^{66}$

Fntretanto, pode-se verificar que na recente guerra do Iraque ${ }^{67}$ o Império norte-Americano optou pela "explosão" do sistema vigente naquele país e até hoje os resultados são aparentemente ruins para o Império. Contudo, mais uma vez percebe-se a associação entre agente privado e Estado, pois as empresas que apoiaram a guerra são beneficiadas para explorar o território conquistado.

Diante da dominação tradicional do Império norte-Americano, que difere e muito do método utilizado no lraque, é de se questionar se os Estados possuem soberania para enfrentar essa dominação.

65 LORDON, John Steelc. An Empire of Wealth: The Epic History of American Economir Power. Nova York: Harper Collins, 2004.

of FERGUSON, Niall. Colossus: the price of America's Empire. Nova Iorque: The Penguin Press, 2004.

67 A guerra do Iraque também leva a pensar acerca dos interesses norte-americanos diante do alto custo financeiro da guerra para os Estados Unidos da América, diante da assertiva de Hannalı Arendt de que: “... a motivação do lucro, cuja importância para a politica imperialista foi freqüentımente exagerada, mcsmo no passado, agora desapareceu, e somente os paises muito ricos e muito poderosos podem suportar as enormes perdas que o imperialismo acarreta" ARENDT. Hannah. Origens do lutulitarismo: Antisemitısmo. Imperalismo. Totalitarismo. Sào Paulo: Companhia das Letras, 2004. p. 150. 
Ora, algumas nações, mais recentemente, ousam a desafiar o Império, como França e Alemanha que se posicionaram contra a guerra do Iraque, e até mesmo o Brasil quando discute as negociações da Área de Livre Comércio das Américas (talvez outra forma de dominação do lmpério a partir do chamado livre comércio).

Mas os resultados ainda são pequenos se comparados ao poder do Império. Aponta-se que os países que enfrentarão o Império norte-Americano nas próximas décadas serão Brasil, Rússia, Índia e China (BRIC). Questiona-se, entretanto, a viabilidade desses paises deterem soberania para desafiar o Império.

Ora, ao vincular-se soberania ao poder econômico, a soberania não é exercida em sua plenitude, não se tem soberania. A dominação do poder econômico acaba por modelar o Estado.

Certamente, o próprio Império Norte-Americano enfrentará dificuldade, terá seu auge, seu apogeu, mas também terá seu declínio. Não se sabe ainda se o declinio já teve início ou se está longe de acontecer.

São Paulo, junho de 2006.

\section{Referências}

ARENDT, Hannah. Origens do tolalitarismo: Anti-semitismo, Imperialismo, Totalitarismo. São Paulo: Companhia das Letras, 2004.

BAGNOLI, Vicente. Introdução ao direito da concorrência: Brasil-Globalização-União EuropéiaMercosul-ALCA. São Paulo: Singular. 2005.

BERCOVICI, Gilberto. Constituição e estado de exceção permanente: atualidade de Weimar. Rio de Janeiro: Azougue Fditoral, 2004.

BITTAR, Fduardo Carlos Bianca; ALMEIDA. Guilherme Assis de. Curso de filosofia do direito. São Paulo: Atlas. 2001.

BOBBIO, Norberto. Studi per una Teoria Generale Del Diritto. Torino: (iiappichelli, 1970.

Teoria Geral da Politica: A filosofia política e as lições dos clássicos. Rio de Janeiro: Campus, 2000.

BODIN, Jean. Los Seis Libros de la Republicu. Madri: Aguilar, 1973.

CÓDIGO de Hamurabi: ('ódigo de Manu, excertos: (livros oitavo e nono): Lei das XII Tábuas. Supervisão editorial Jair Lot Vieira. I^ed. Bauru: EDIPRO. (Série Clássicos) 
DELMANTO, Celso. Crimes de concorrência desleal. São Paulo: José Bushatsky Editor, 1975.

FERGUSON, Niall Colossus: the price of America's Empire. Nova Iorque: The Penguin Press, 2004.

FERRAZ JUNIOR. Tércio Sampaio. Estudos de Filosofia do Direito: Reflexões sobre o Poder, a Liberdade, a Justiça e o Direito. São Paulo: Atlas, 2002.

FONSECA, João Bosco Leopoldino da. Direito Econômico. 4. ed. rev. e atual. Rio de Janeiro: Forense, 2001.

FORGIONI, Paula A. Os fundamentos do Antitruste. São Paulo: Revista dos Tribunais, 1998.

FURLAN, Fernando de Magalhães. Integração \& Soberania: o Brasil e o Mercosul. São Paulo: Aduaneiras, 2004.

GORDON, John Steele. An Empire of Wealth: the epic history of American Economic Power. Nova York: Harper Collins, 2004.

GRAU, Eros Roberto. A ordem econômica na Constituição de 1988. 8. ed. São Paulo: Malheiros, 2003.

HARDT, Micahel; NEGRI, Antonio. Império. São Paulo: Record, 2004.

HEGEL, Georg Wilhelm Friedrich. Filosofia da História. 2. ed. Brasília: UnB, 1999. . Principios da Filosofia do Direiro. São Paulo: Martins Fontes, 2000.

HIRST, Paul; THOMPSON, Grahame. Globalização em questão. Petrópolis: Vozes, 1998.

HOBSBAWN, Fric. Da Revolução Industrial Inglesa ao Imperialismo. 5. ed. Rio de Janeiro: Forense Universitário, 2003.

. Era dos Extremos: O breve século XX, 1914-1991. 2. ed. São Paulo: Companhia das Letras, 1995.

IHERING, Rudolf Von. A luta pelo Direito. Tradução João Vasconcelos. 17. ed. Rio de Janeiro: Forense, 1999.

KAPLAN, Abraham; LASSWELL, Harold. Poder e sociedade. Brasília: UNB.

LAFER, Celso. Direito e poder na reflexão de Miguel Reale. In: Miguel Reale na UVB. Brasília: UNB, 1981.

. A identidade internacional do Brasil e a Politica Externa brasileira: passado, presente e futuro. São Paulo: Perspectiva, 2001. 
LITVIN, Daniel. Empires of Profit: ('ommerce, Conquest \& Corporate Responsability. EUA: Thomson, 2003.

MARANHÃO, Délio; CARVALHO, Luiz Inácio B. Carvalho. Direito do Trabulho. 17. ed. Rio de Janeiro: Fundação Getúlio Vargas. 1996.

MARX. Karl. O Capital. Tradução Gabriel Deville. Edição condensada. Bauru: Edipro, 1998.

MASCARO, Alysson Leandro. Introdução à Filosofía do Direito: dos Modemos aos Contemporâneos. São Paulo: Atlas, 2002.

NUSDEO, Fábio. Fundamentos para uma codificação do Direito Econômico. tese apresentada em 1993 à Faculdade de Direito da Universidade de São Paulo para Concurso de provimento de cargo de Professor Titular do Departamento de Direito Econômico e Financeiro

PERA, Alberto. Concorrenza e Antitrust. 2. ed. Bologna: il Mulino, 2001.

REALE, Miguel. Filosofia do Direito. 19. ed. São Paulo: Saraiva. 1999. Lições preliminares de direito. 21. cd. São Paulo: Saraiva, 1994.

REZEK, José Francisco. Direito Internacional Púhlico: curso elementar. 6. ed. São Paulo: Saraiva, 1996.

SALOMÃO FILHO. Calixto. Direito concorrencial: as estruturas. São Paulo: Malheiros, 1998.

SOLON, Ari Marcelo. Teoria da soberania como problema da norma juridica e da Decisão. Porto Alegre: Sergio Antonio Fabris Editor, 1997.

SOUZA, Washington Peluso Albino de. Primeiras linhas de direito econômico. 5. ed. São Paulo: LTr, 2003.

STIGLITZ, Joseph E. A Globalização e seus maleficios. São Paulo: Futura, 2002.

TOFFLF, Alvin. A Terceira Onda. 6. ed. São Paulo: Record, 1986.

WEBF.R, Max. Economia e sociedade. Tradução Regis Barbosa e Karen Elsabe Barbosa. 4. ed. Brasília: Editora Universidade de Brasília, 2000, v. 1.

Economia e sociedade. Tradução Regis Barbosa e Karen Elsabe Barbosa Brasilia: Editora Universidade de Brasília, 1999. v. 2.

WITTGENSTEIN, Ludwig. Investigações filosóficas. Tradução José Carlos Bruni São Paulo: Nova Cultural. 2000. (Série Os Pensadores). 